بسلم الله الرحمز الرهيم

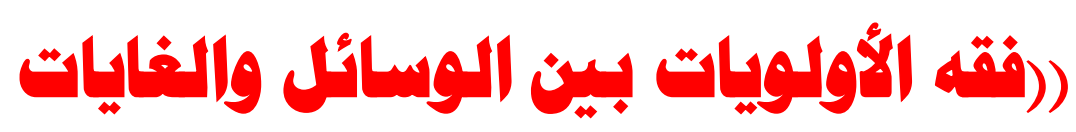

$$
\begin{aligned}
& \text { ، دراسة هماصدية في الاجتهاد الذرائمي)) } \\
& \text { إعداد } \\
& \text { د.طارق أسعد حلمي الأسعد } \\
& \text { أستاذ الفكر الإسلامي والإسلام و قضايا العصر المشارك } \\
& \text { الجامعة الهاشئة ـ الأردن- الزرقاءع }
\end{aligned}
$$


"فقه الأولويات بين الوسائل والغايات،دراسة مقاصدية في الاجتهاد الذرائعي" 


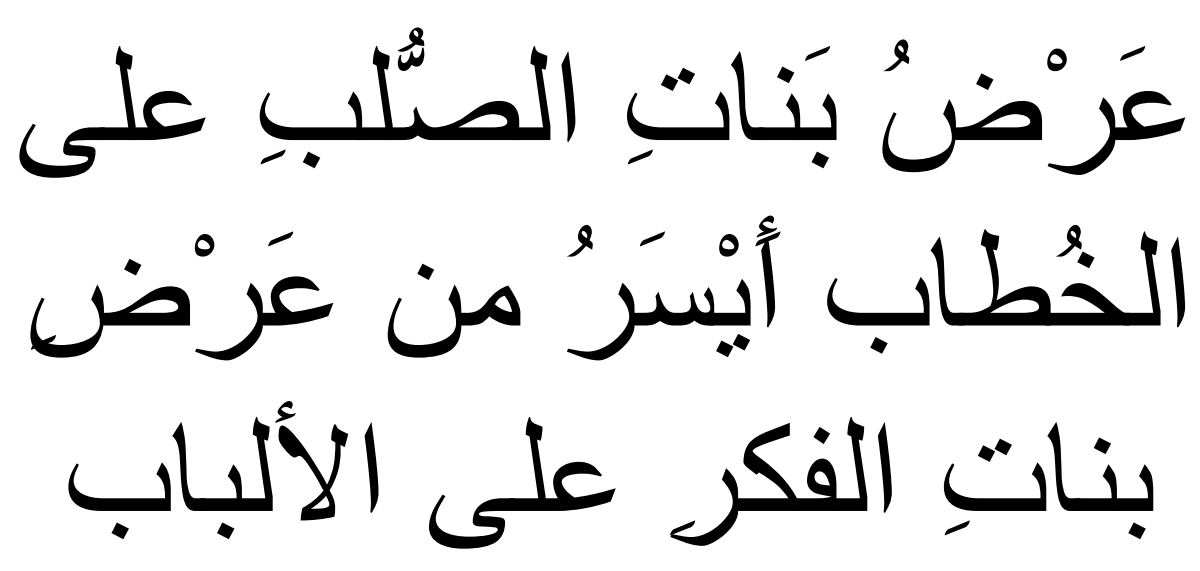

مقولة منسوبة للأصفهاني ولم أعثر عليها وذكرتها لأنها من المُلح و اللطائف 
"فقه الأولويات بين الوسائل والغايات،دراسة مقاصدية في الاجتهاد الذرائعي"

((فقةه الأولويات بين الوسائل والغايات، دراسة مقاصدية في الاجتهاد الذرائعي)(

$$
\text { طارق أسعد حلمي الأسعد. }
$$

قسم المواد الإنسانية المساندة ، كلية الآداب ، الجامعة الهاثمية ، الزرقاء ، الأردن.

tarq@staff.hu.edu.jo: البريد الإكتروني

الملخص:

ترسم هذه الدراسة حدود الذرائعية، وتبين مسالكها في مقارباتها الأغلبية التي

تمحص النظر في ما هو الأوْلى بلوغُه، مما يقبل التطبيق الأقرب لمفهوم المصلحة بكل مستوياتها الضرورية و الحاجية و التحسينية، وذللك تأسيسأ للذر ائعية المستمرة في تحسين أدائها و الظافرة بمطالبها الثاوية في مقاصدَ تَتَبَعُها وسائلها التي تؤثر في اقتضاء المعنى المناسب في محل الحكم ، وقد تقرر في هذه الدر اسة النظر في ما يُفضي الى استدعاء ماهو الأوْلى الذي صار إليه المحققون وبلغه اجتهادهم وشدةٌ توقيهم في التحري عن اعتبار المآلات وتحصيل المقاصد،ثم العمل على استبنائه تحقيقأ وتأصبلا. الكثمات المفتاحية: فقه الأولويات ، دراسة مقاصدية ، الاجتهاد الذرائعي ،اعتبار المآل ، الأولى في الحقيقة وفي نفس الأمر ، تحقيق المناط ، تنقيح المناط، فقه الموازنات، حصول التسويغ المستمر، البيان النازل في محله، الاقتضاء الأصلي، الاقتضاء التبعي، إقتضاء المعنى المناسب، إستظهار مراد الثارع، الوسيلة تتبع مقصدها، إستبناء الأولى، إستدعاءُ الأولى، النظر الأصوليُ ، النظر المصلحي، سدُ الذرائع ، التمسك بالبر اءة 


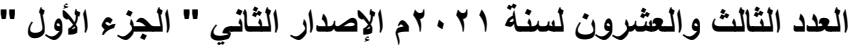

مجلة كلية الثريعة والقانون بتفهنا الأشر اف ـ دقهلية

"Jurisprudence of priorities between means and objectives، a purposeful study in the jurisprudence of pretexts"

Tarek Asaad Helmy Al Asaad

Department of Allied Humanities, Faculty of Arts, The Hashemite University ,Blue, Jordan.

Email : tarq@staff.hu.edu.jo

Abstract:

This study draws the limits of pretexts، and shows its courses in its approaches the majority that considers what is the first to reach، which accepts the closest application of the concept of interest at all its necessary levels، need and improvement، based on the constant pretexts in improving its performance and triumphant with its second demands in purposes followed by its means that affect the requirement of the appropriate meaning in the place of judgment، and it was decided in this study to consider what leads to the recall of what became the first which became the investigators and in the language of their diligence and the severity of their investigation Considering the machinery and collecting the purposes، and then working to adopt it as an investigation and rooting.

keywords: The jurisprudence Of priorities, The Study Of Intention, The Pragmatic Diligence, The Consideration Of Money, The Priority In The Truth and in the same matter, The Fulfillment Of The Mandate, The Revision Of The Point, The Jurisprudence Of Balances, The Occurrence Of Continuous Justification, The Statement Descending in its Place, The Original Requirement, The Accessory Requirement, TheRequirement Of The Appropriate Meaning, The Invocation Of The Will Of The Street The Means Follow Its Purpose, The Construction Of The Former, The Invocation Of The Former, The Fundamentalist Consideration , The Conciliatory Consideration, Blocking The Pretexts , Adhering To The Original Innocence. 


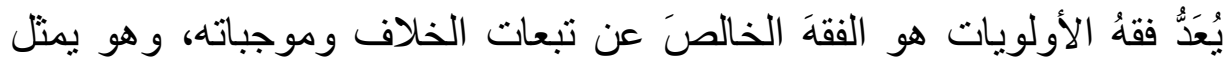

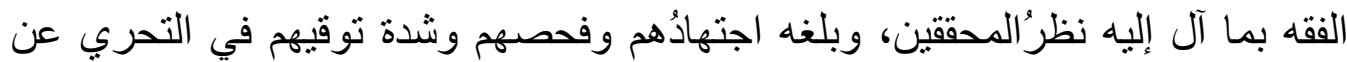

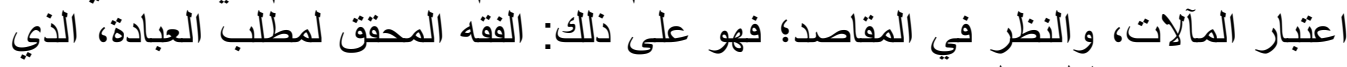
إن فقه الأولويات: هولب العباد الفقه بما هو الأولى في الحقيقة وفي نفس الأمر، أي في

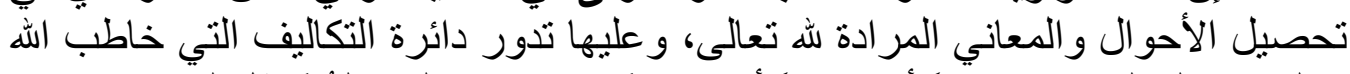

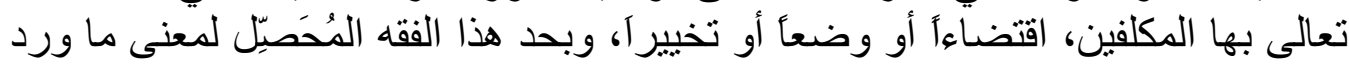

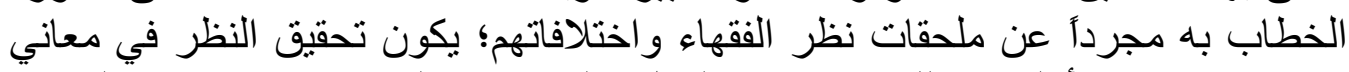

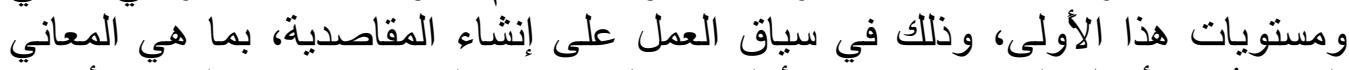

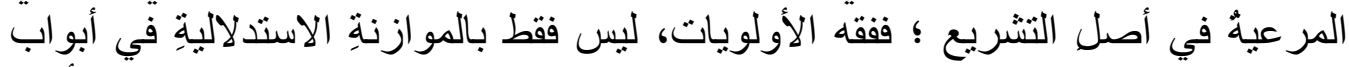

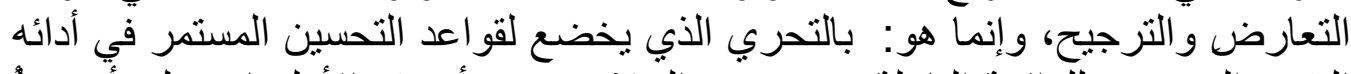

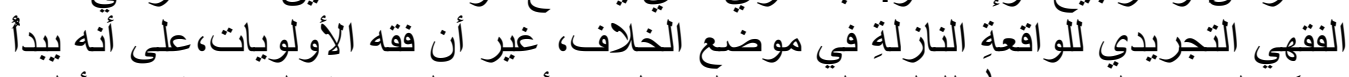

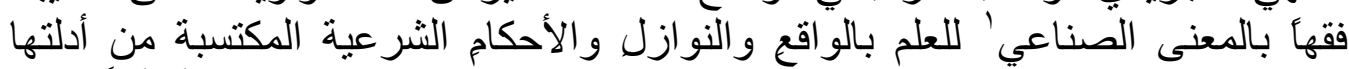

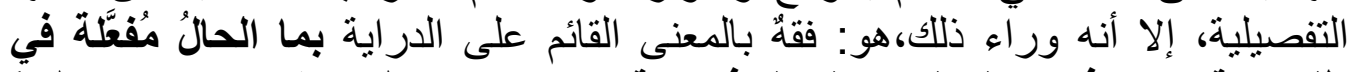

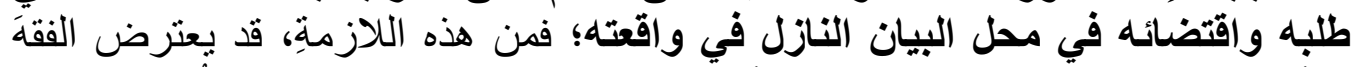

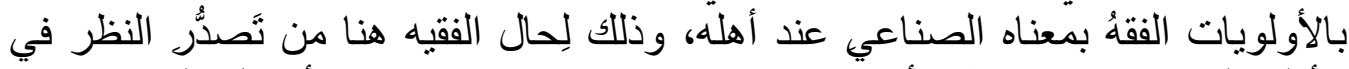

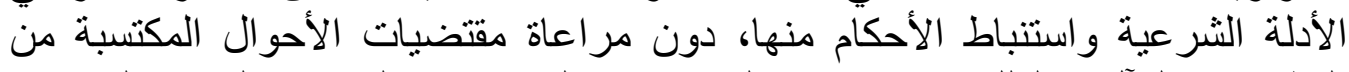

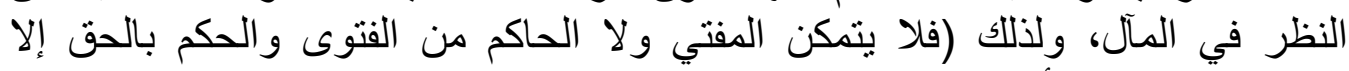

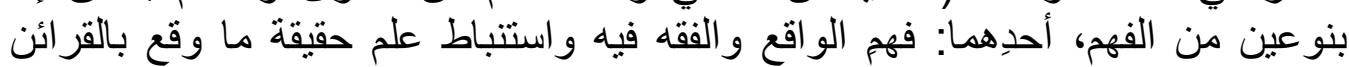

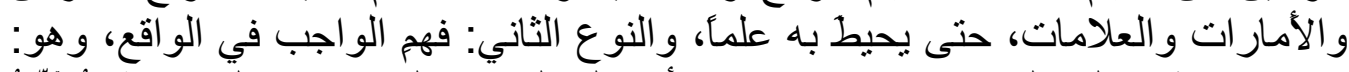

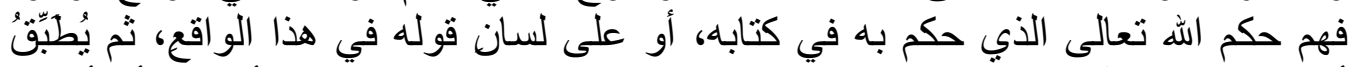

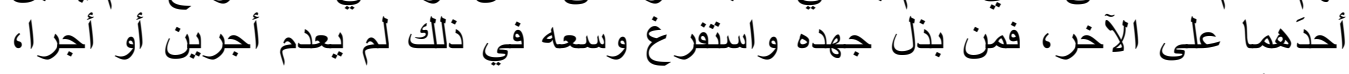

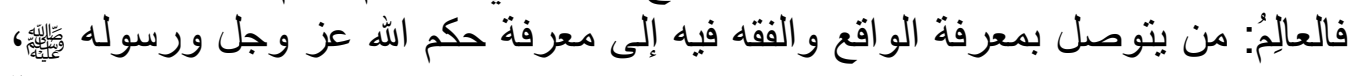

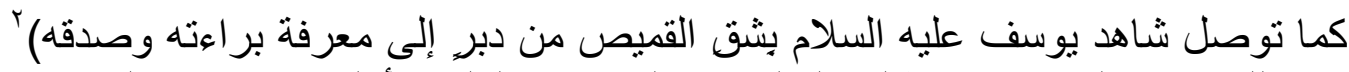

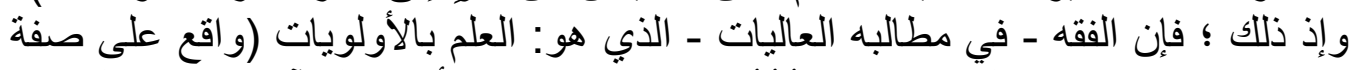

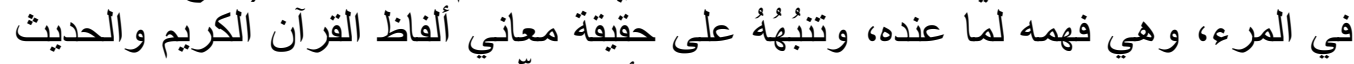

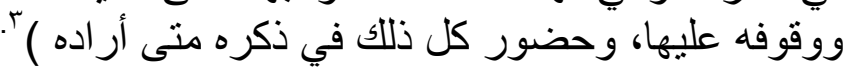

'المعنى الصناعي: أب أن يكون المعنى الصناعي المنقول إلبه الاسم مشابها للمعنى الجمهوري

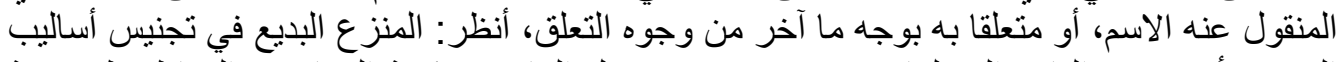

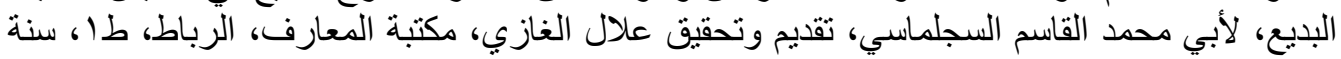

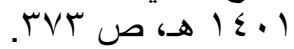

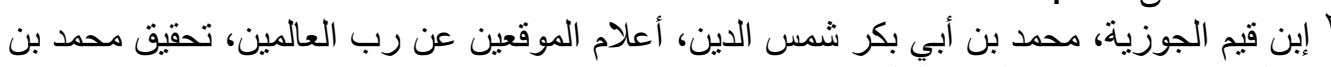

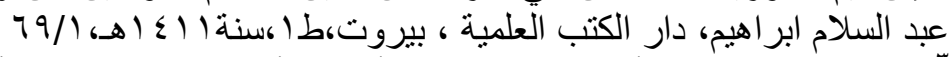

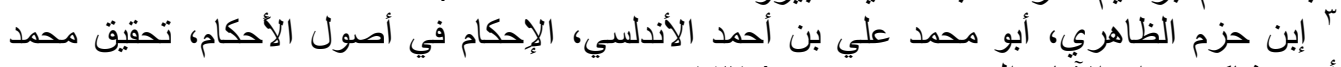

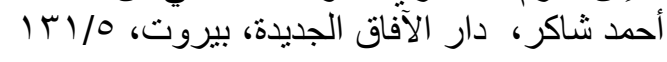


(فليست تنزل بأحد عن أهل دين الله تعالى نازلة،إلا وفي كتاب الله تعالى الدليل

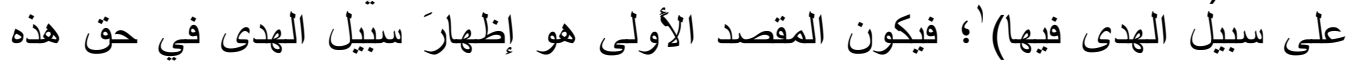

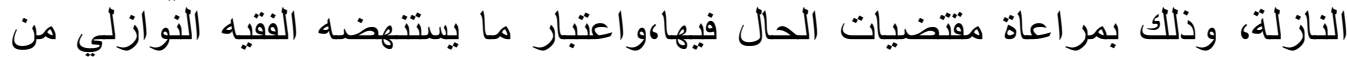

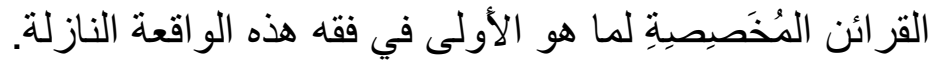

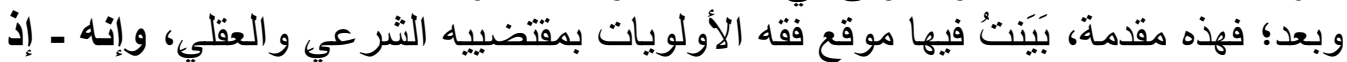

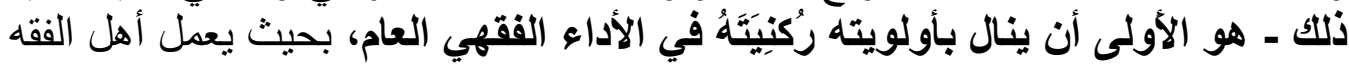

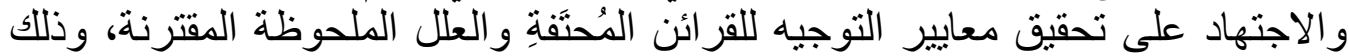

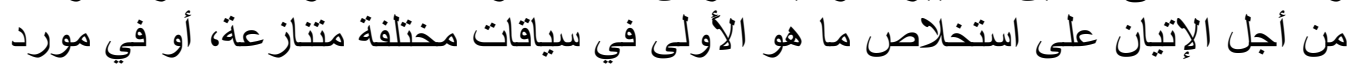

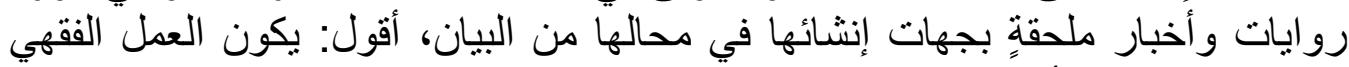

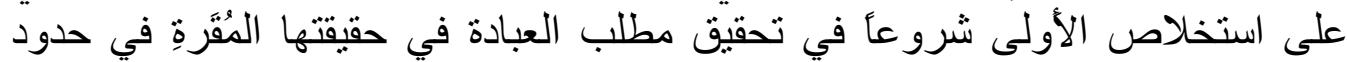

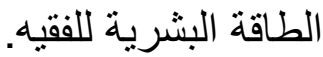

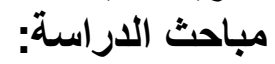

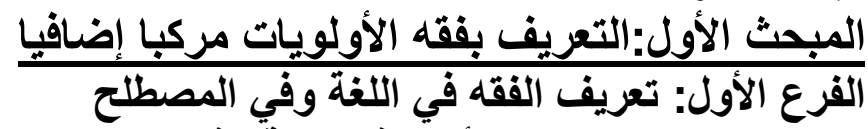

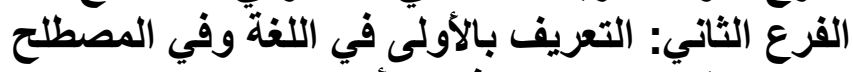

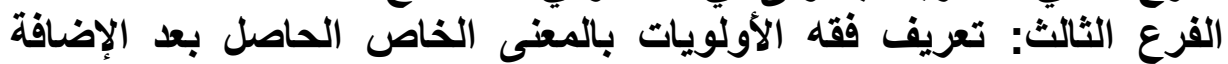
المركبة المبحث الثاني:فقه الأولويات بين الوسائل الممكنة والغايات المناسبة في

الحال و المآل

الألبحث الأثالث:أسس فقه الأولويات

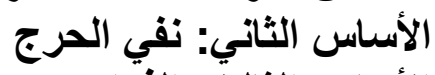

الأساس الثالث: الأريائع الحرع

المبحث الرابع:أثر الاجتهاد الذرائعى في تحقيق أصول فقه الأولويات وتطبيقاته المقاصدية. المبحث الخامس:نماذج من تطبيقات فقه الأولويات واستدلالات الفقهاء

' الثافعي، محمد بن إدريس، الرسالة، تحقيق أحمد محمد شاكر، دار الكتب العلمية، بيروت، لبنان، $-V M r-$ 


\section{الاببمث الأول}

\section{التعريف بفقه الأولويات هركبًا إضافيًا}

\section{الفرع الأول \\ تعريف الفقه في اللغة وفي المصطيح}

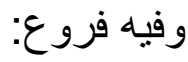

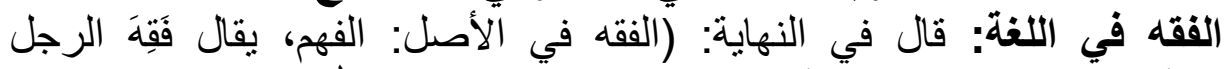

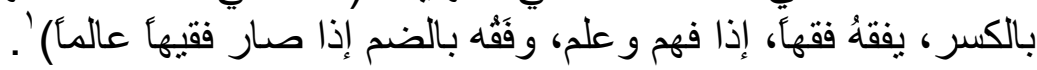

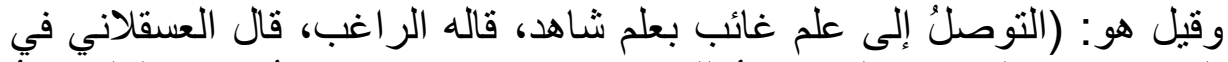

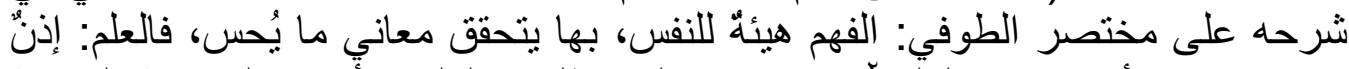

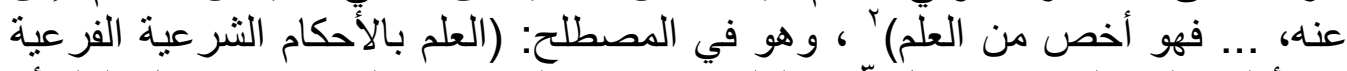

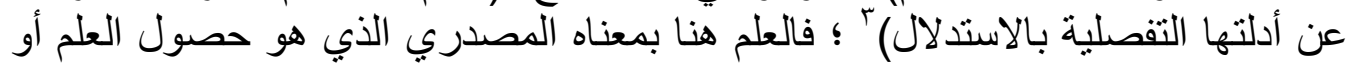

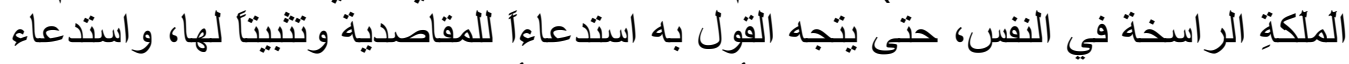

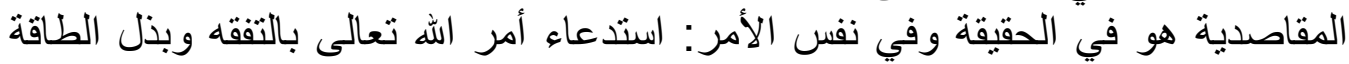

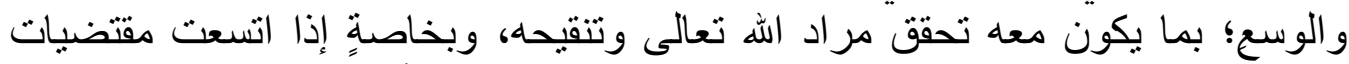

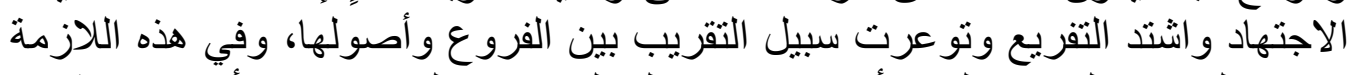

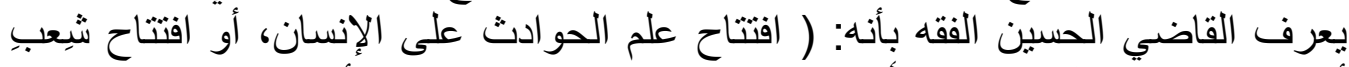

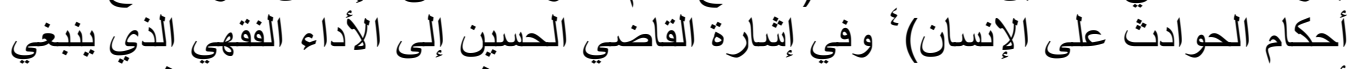

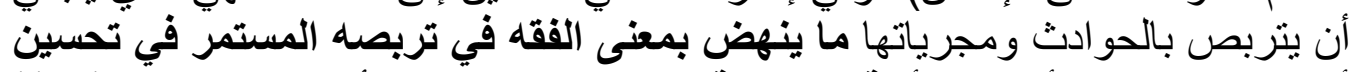

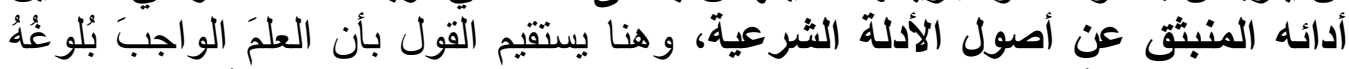

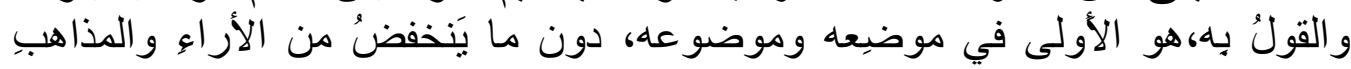

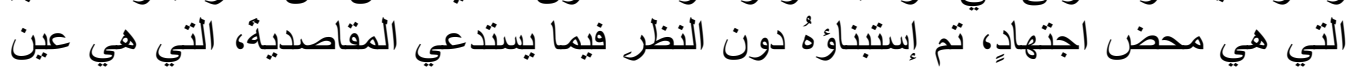

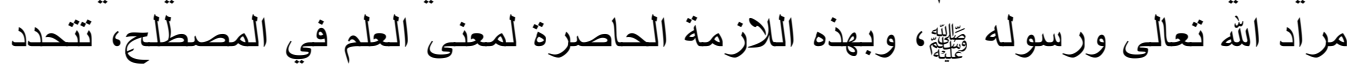

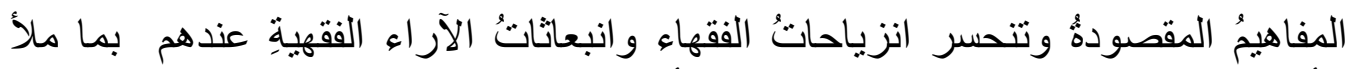

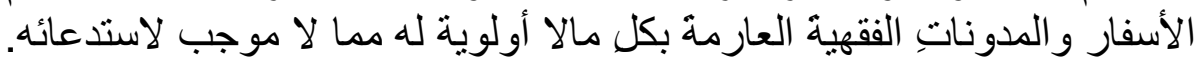

إبن الأثير، النهاية في غريب الحديث،تحقيق طاهر أحمد الراوي،مؤسسة اسماعيليان للطباعة

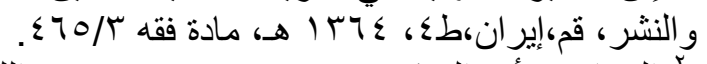

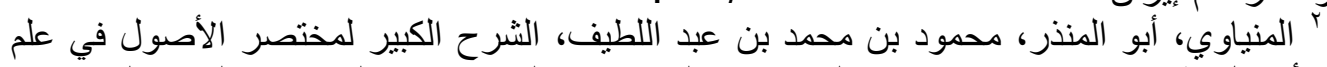

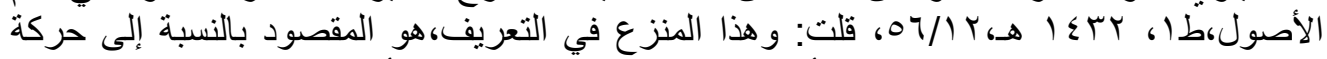

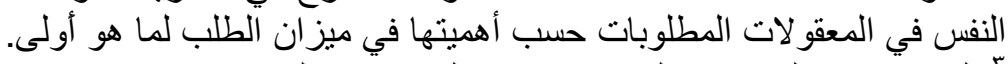

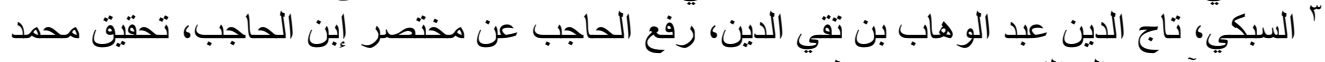

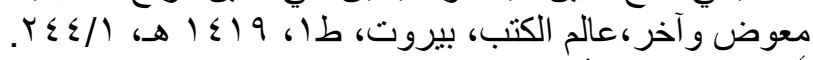

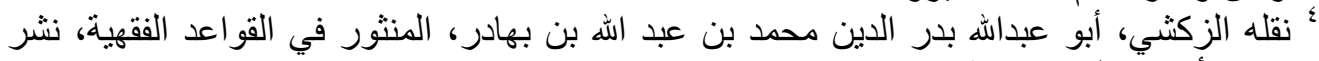




\section{الفرع الثاني \\ تعريف الأولى في اللغة وفي المصني}

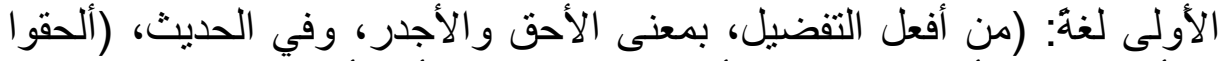

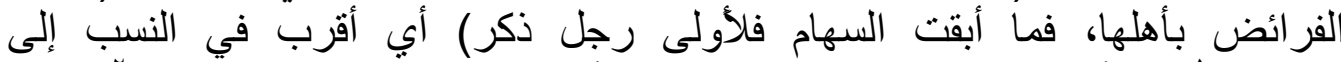

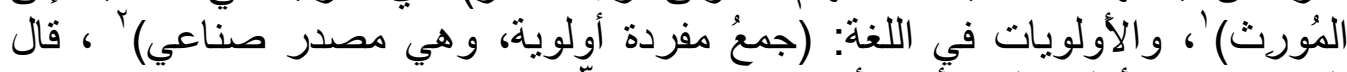

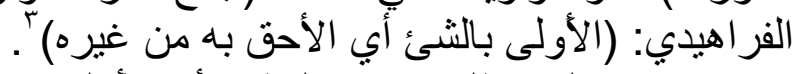

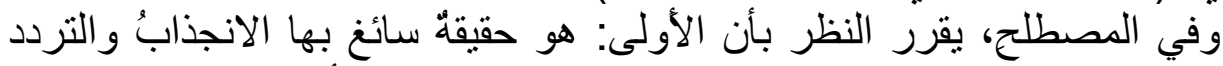

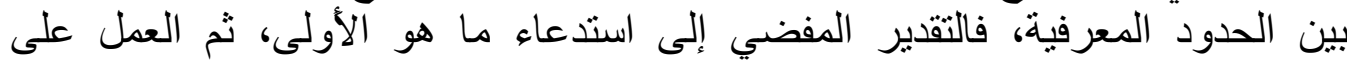

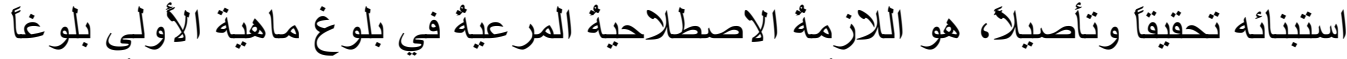

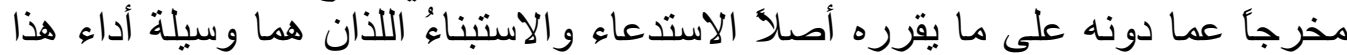

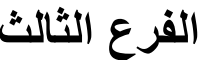

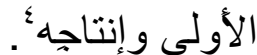

\section{تعريف فقه الأولويات بالمعنى الخاص الحاصل بعد الإضافة المركبة}

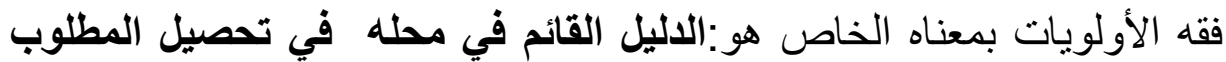

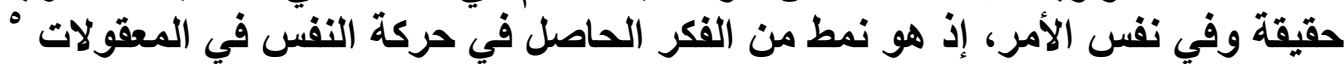

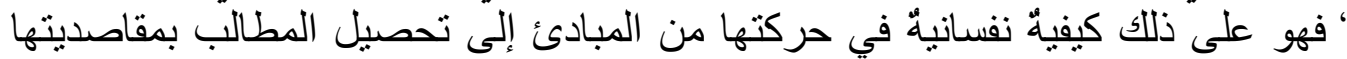

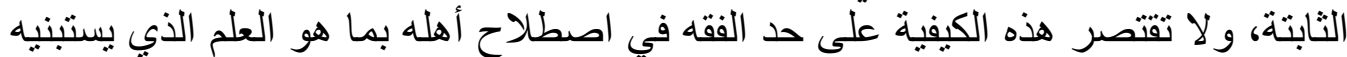

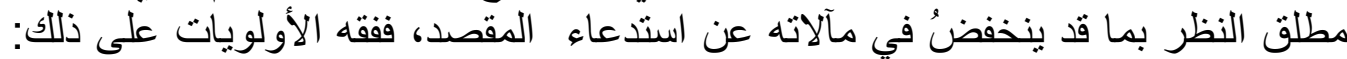

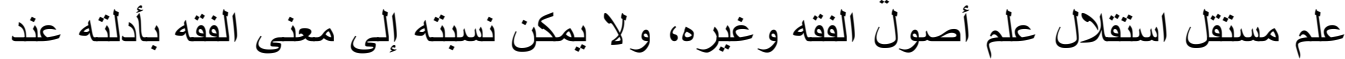

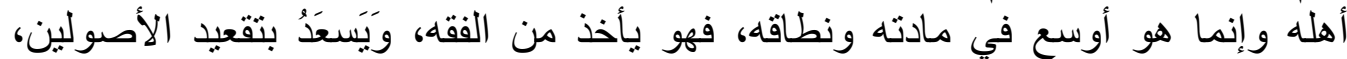

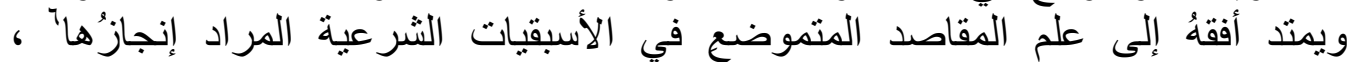
و المدعنُ في عبار ات المعرفين لهذا الفقه القائم على الأدلة في معقولها لهات ووحي مقاصديتها

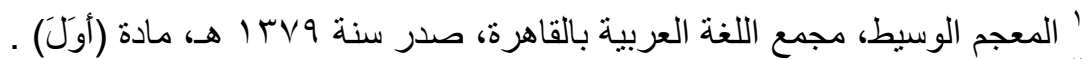

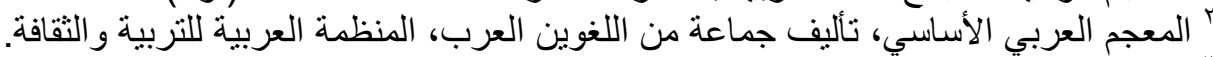

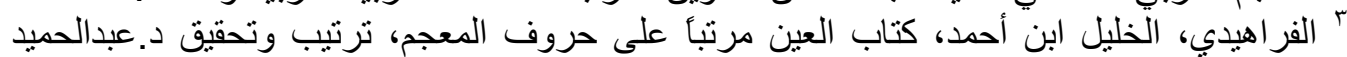

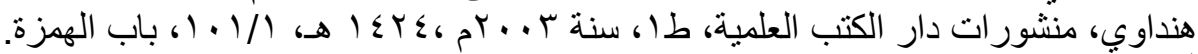

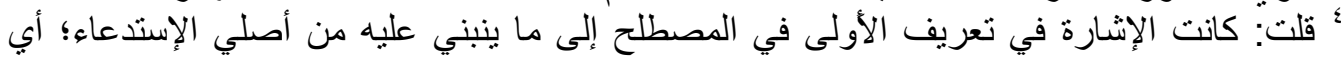

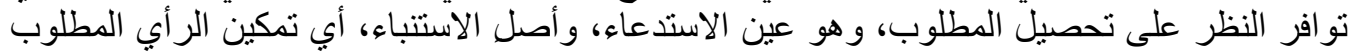

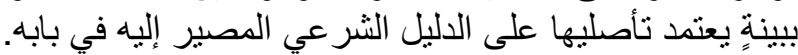

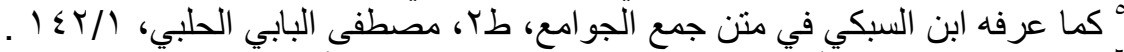

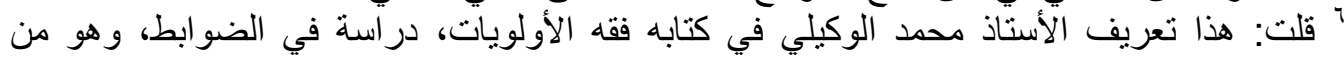

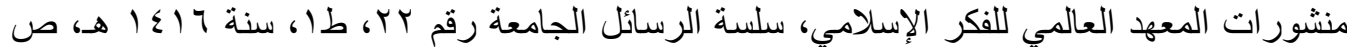




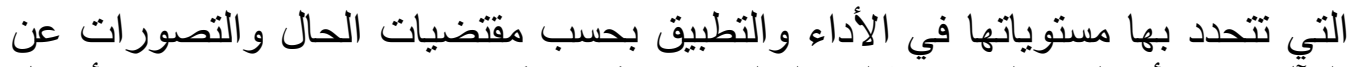

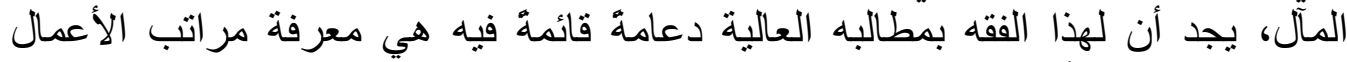

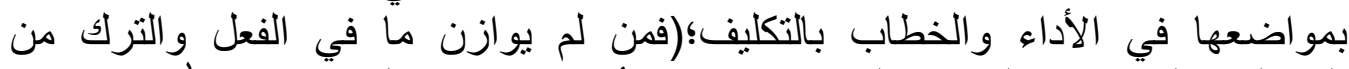

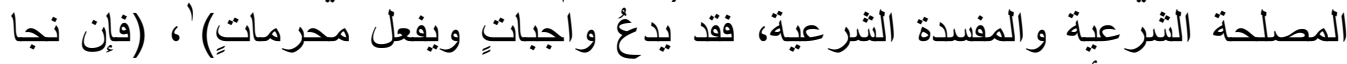

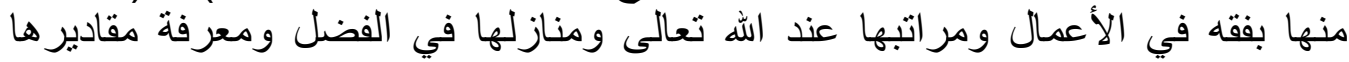

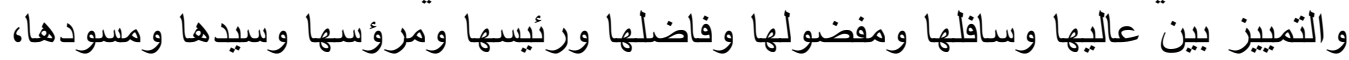

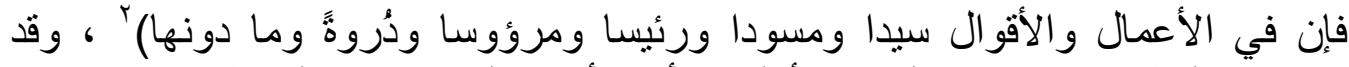

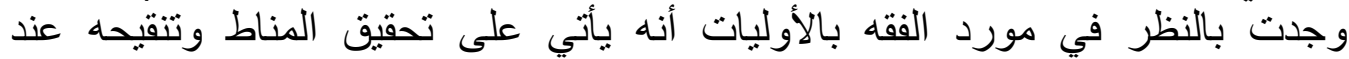

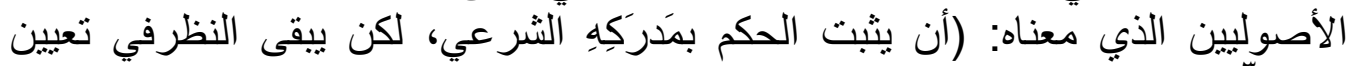

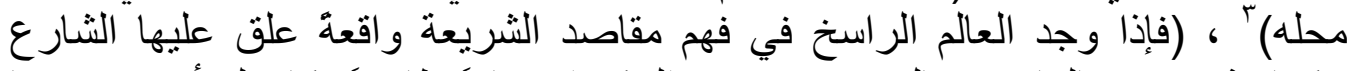

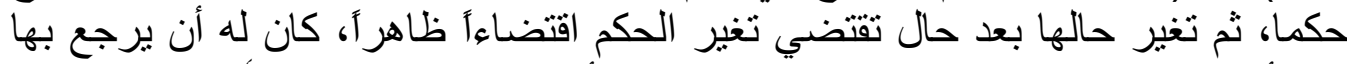

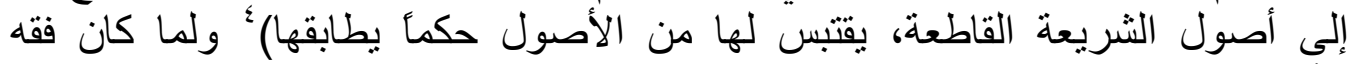

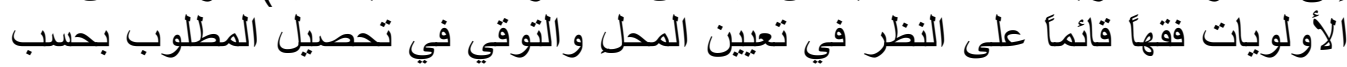

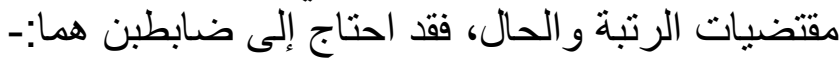

الأول: أنه يصار إليه في تقديم ما يوجب النظرُ تقديمَهُ في حال التعارض ونز الإنه احم الأدلة،

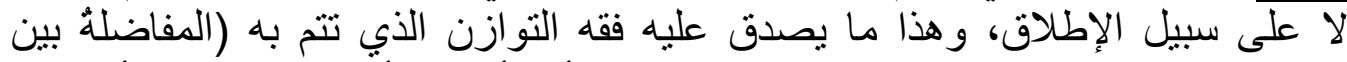

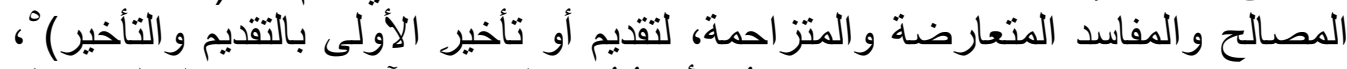

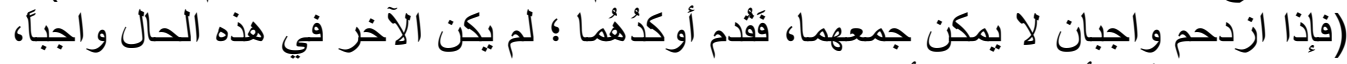

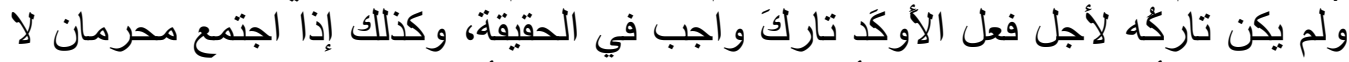

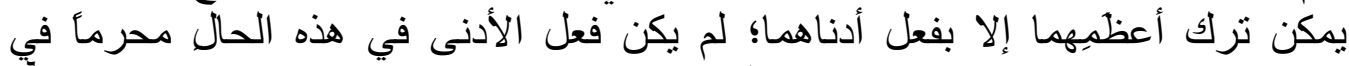

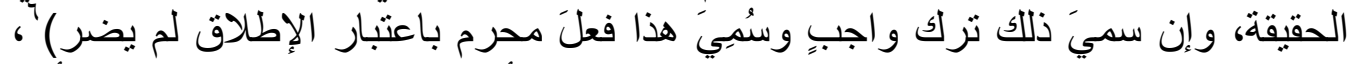
هذا وقد نهضت الحاجة إلى فقه الموازنات في هذه الأعصدار التي تزاتئ احمت فيها الأدلة

إبن تيمية، تقي الدين أحمد بن عبدالحليم، مجموع فتاوى، تحقيق عبدالرحمن بن محمد بن قاسم،

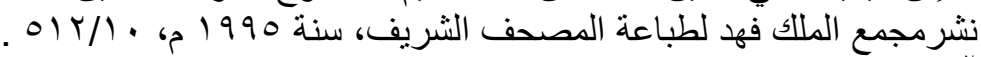

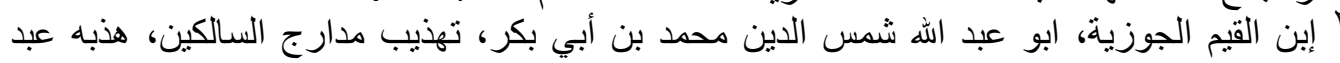

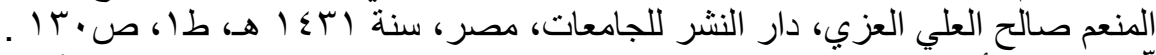

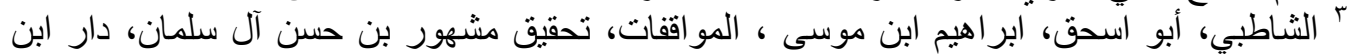

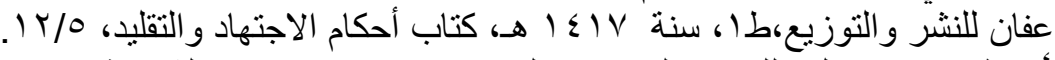

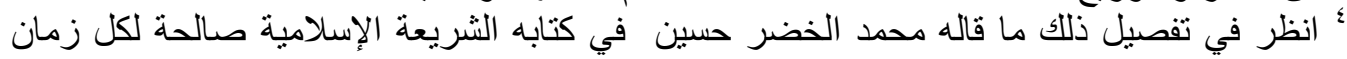

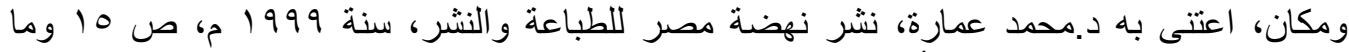

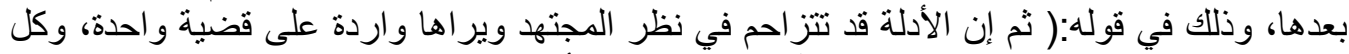

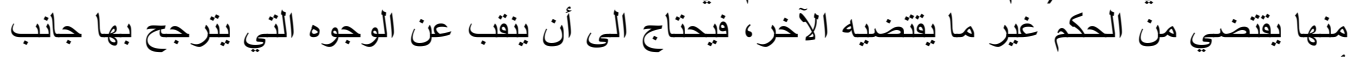
أحدها ليعتمد عليه في تقرير الحكم. في الحير.

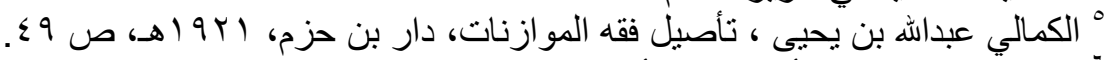

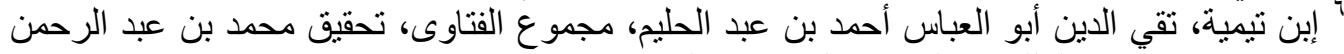

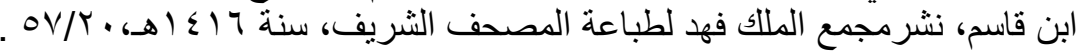


واتسعت فيها أبواب التعارض، (لاسيما في الأزمنة والأمكنة التي نقصت فيها آثار

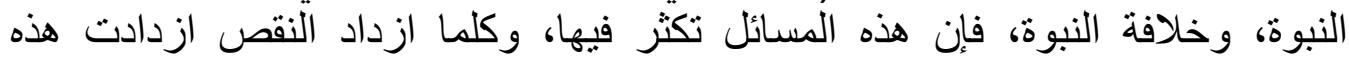
المسائل، ووجود ذللك من أسباب الفتنة بين الأمة) '.

الثانى: أن الموازنة المصبر إليها في فقه ما هو أولى لاستحقاقاته المعللة

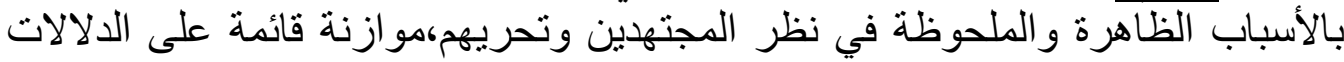

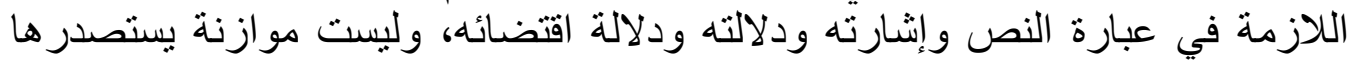

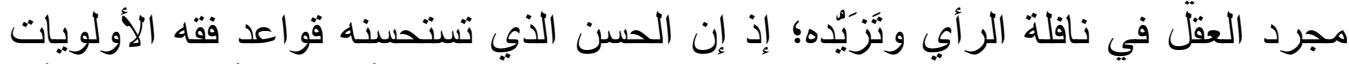

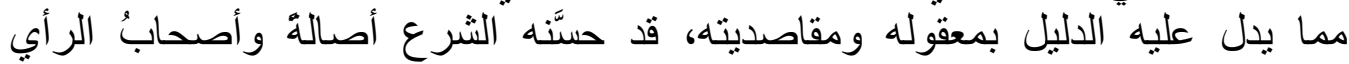

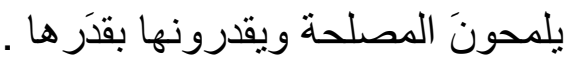




\section{المبمث الثاني}

\section{فقه الأولويات بين الوسائل الممكنة والغاليات المناسبة في الهال والمآل .}

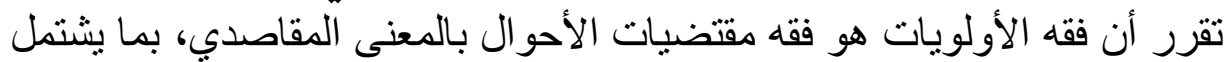

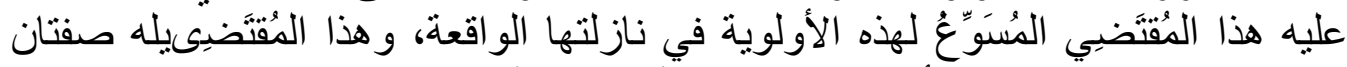

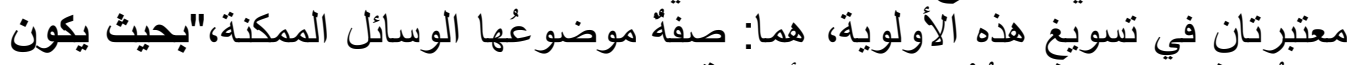

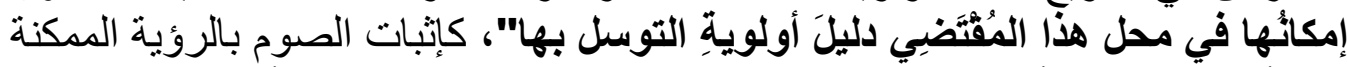

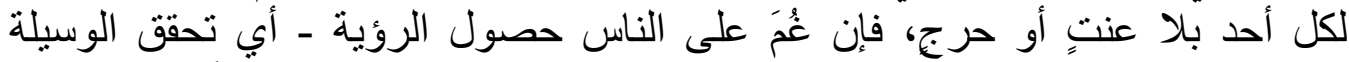

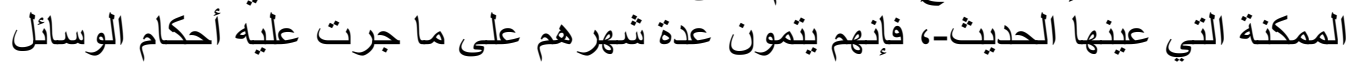

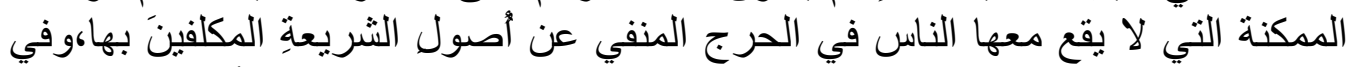

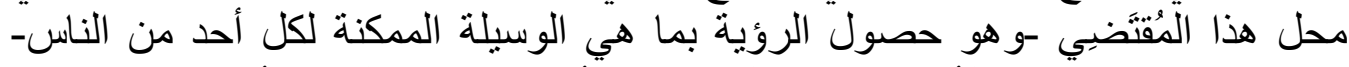

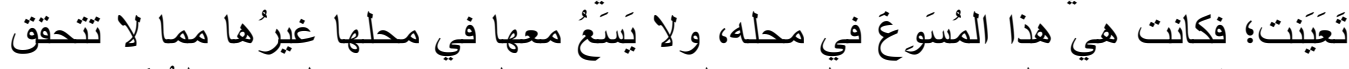

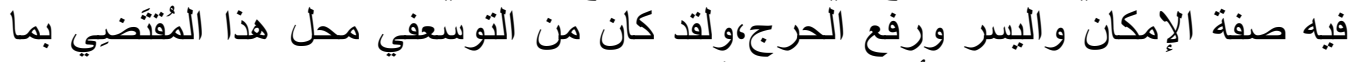

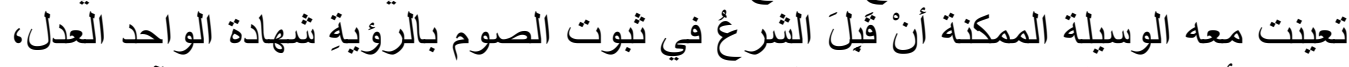

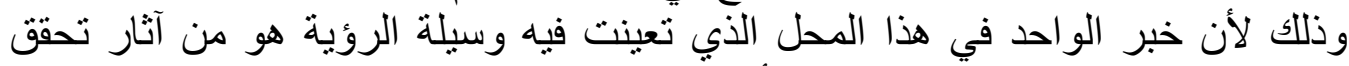

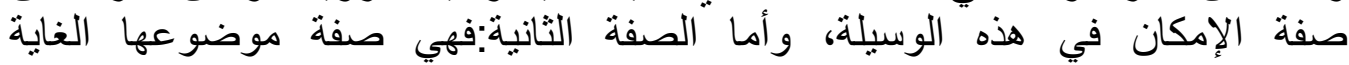

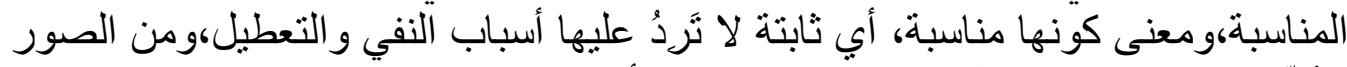

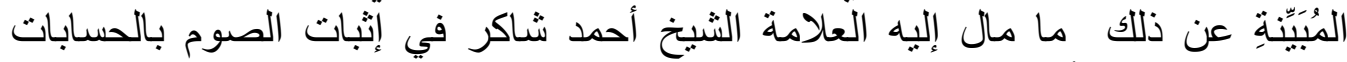

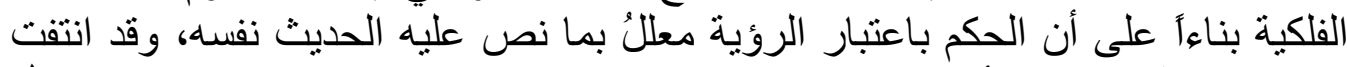

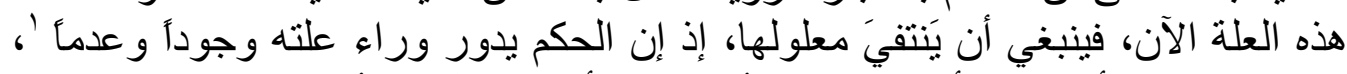

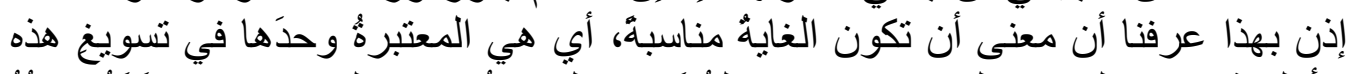

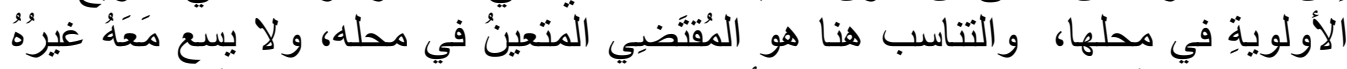

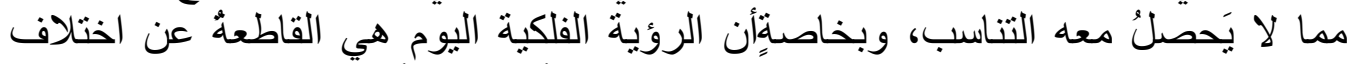

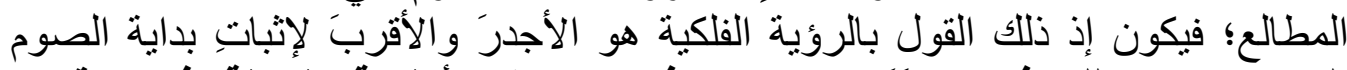

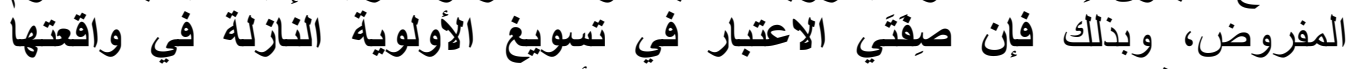

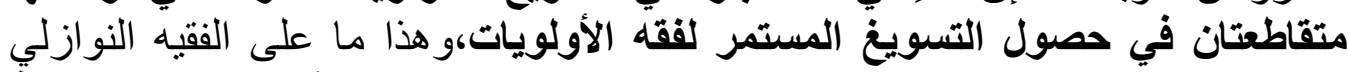

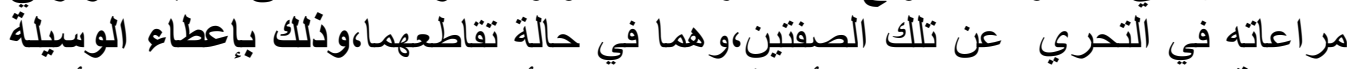

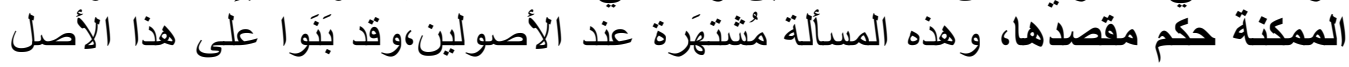

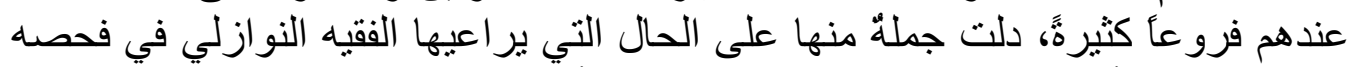

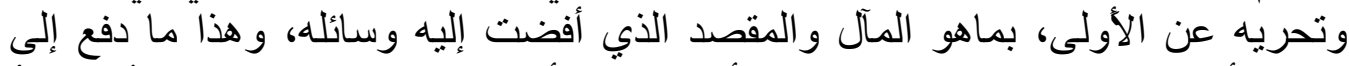

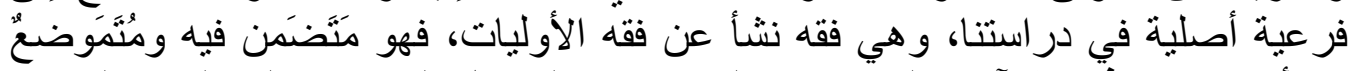

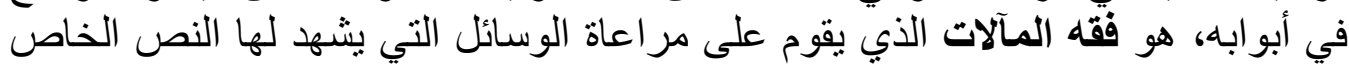
و العام باعتبار ها ومشرو عيتها المالات التهي

أنظر رسالة (أو ائل الثهور العربية، هل يجوز شر عا إثباتها بالحساب الفلكي ) للعلامة الثيخ أحمد محمد

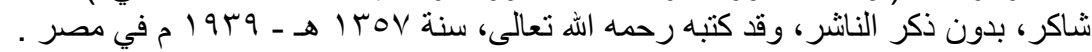


إذن، إن فقه الأولويات قائمُ في محله المتعين به على وسيلة ممكنة تؤدي بإمكانها

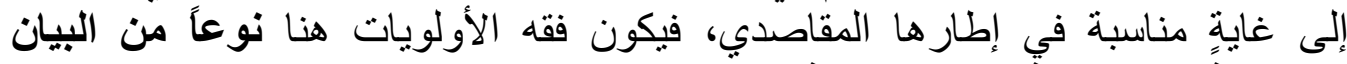

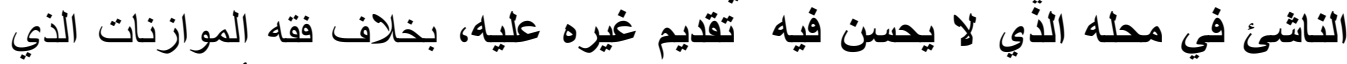

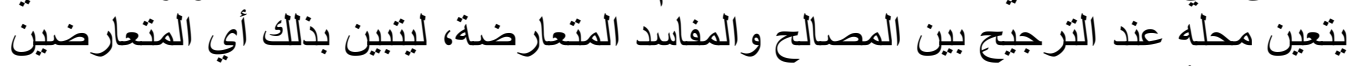

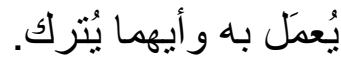

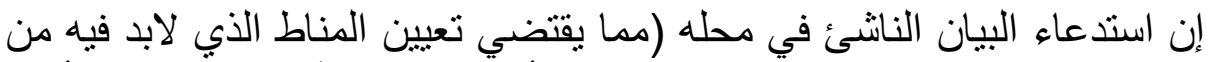

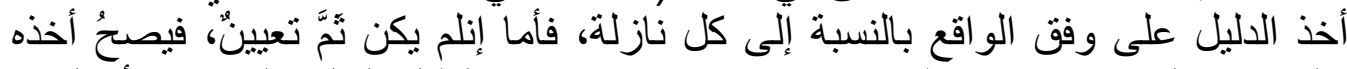

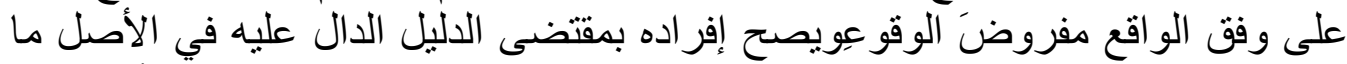

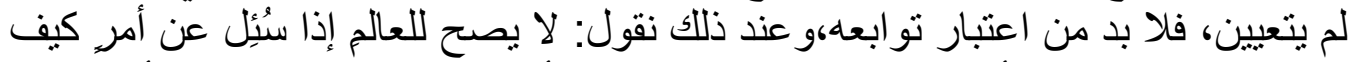

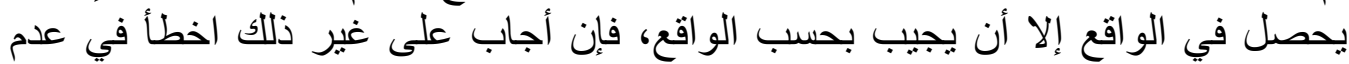

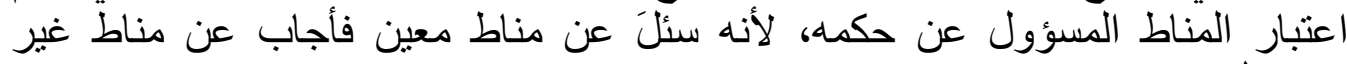
معين)'

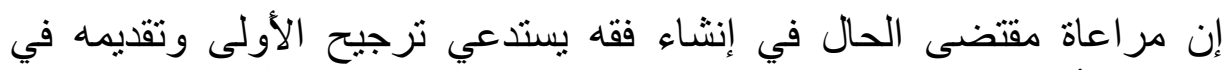

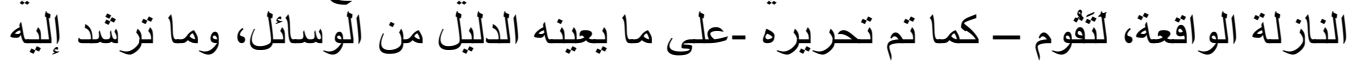

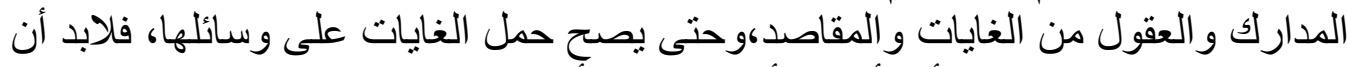

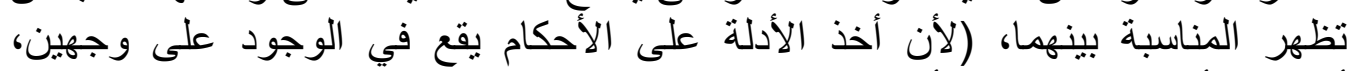

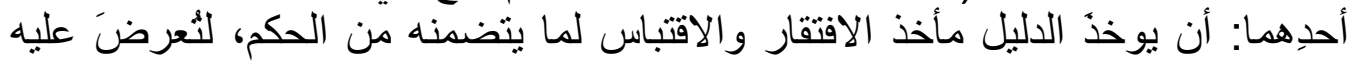

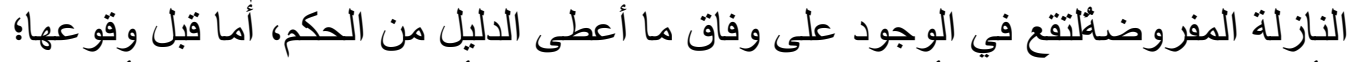

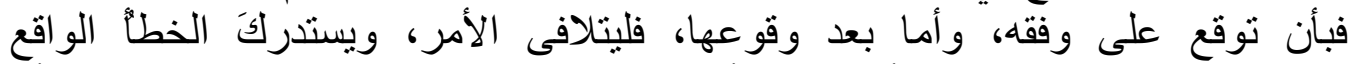

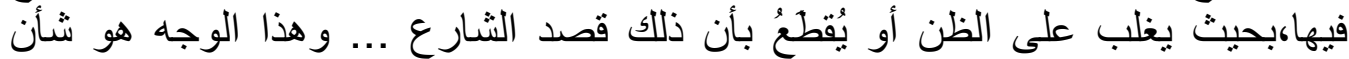

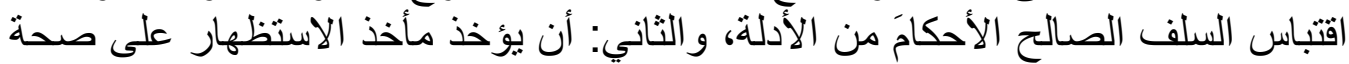

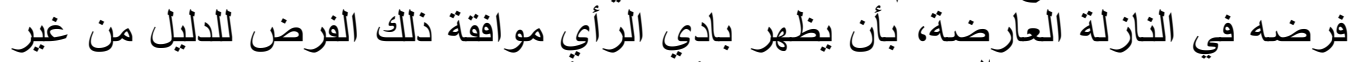

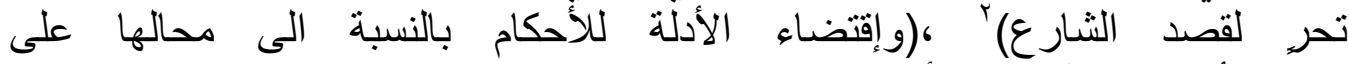

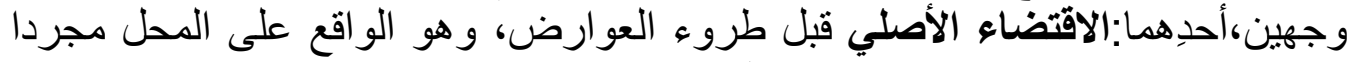

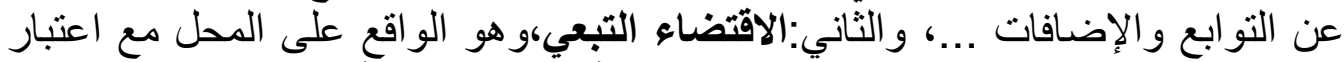

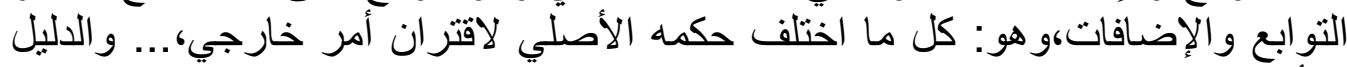

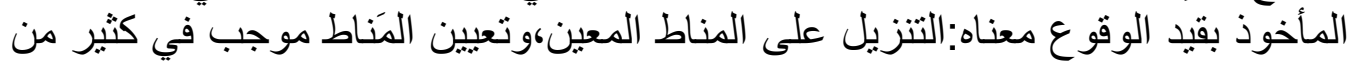

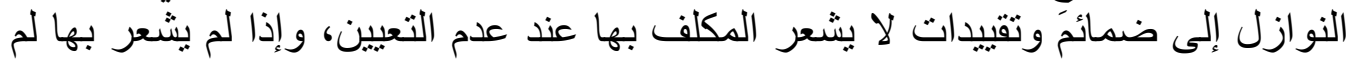

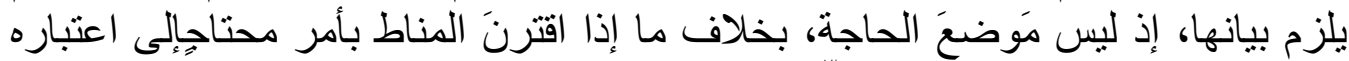

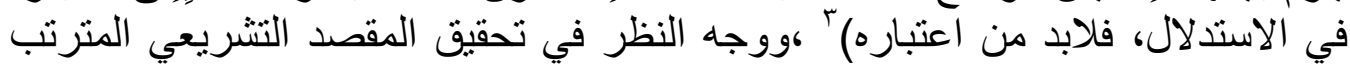

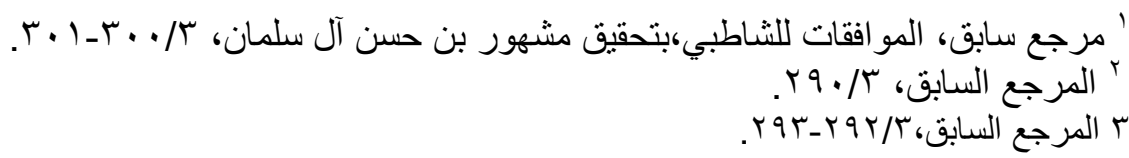


على تقرير المصلحةِ إنما هو (من حيث تعلقُ الخطاب بها شر عا، فالمصلحة إذا كانت

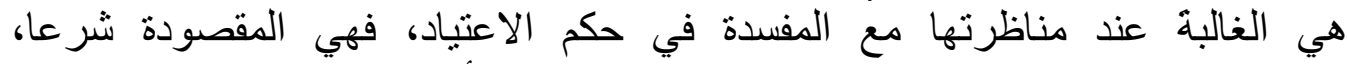

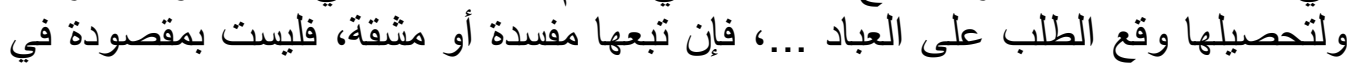

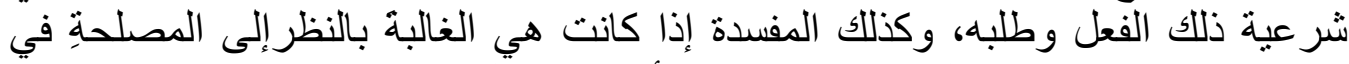

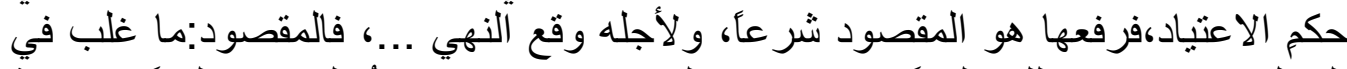

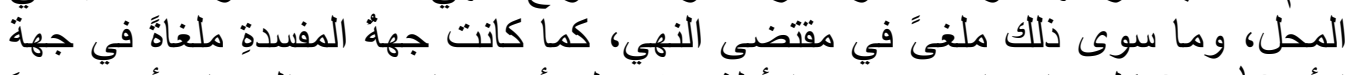

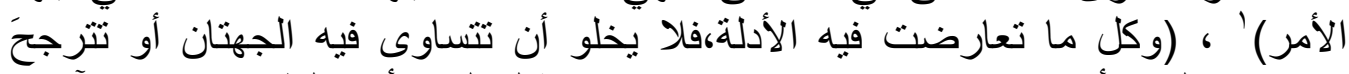

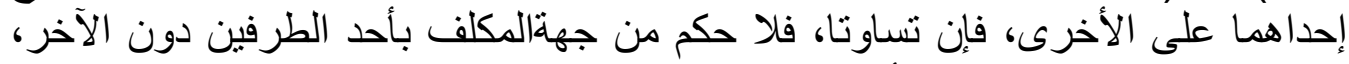

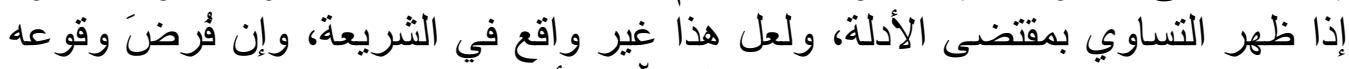

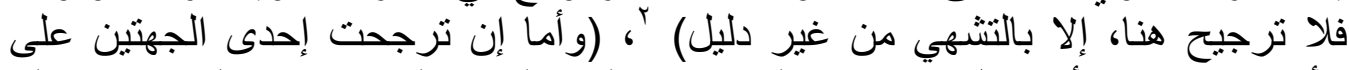

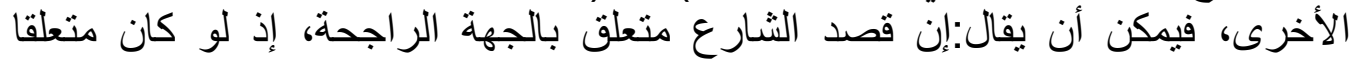

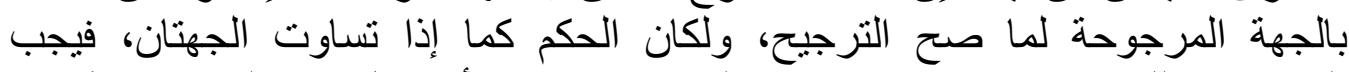

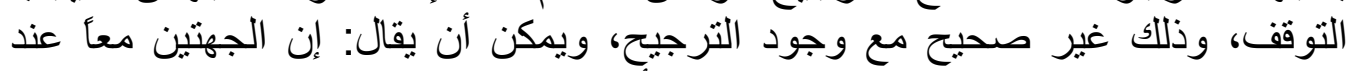

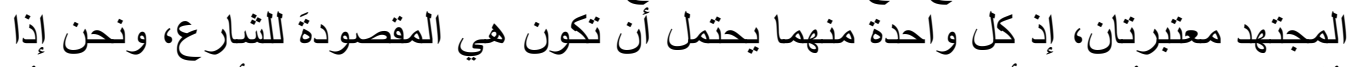

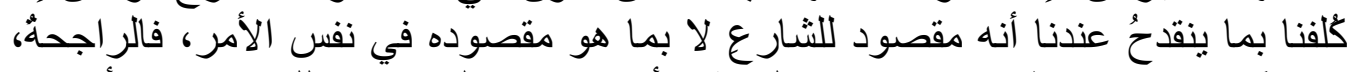

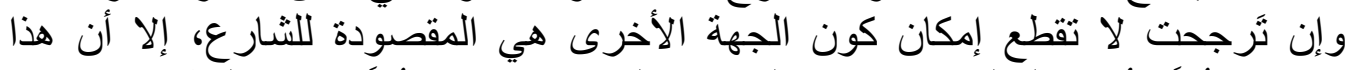

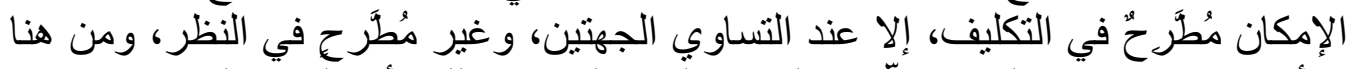

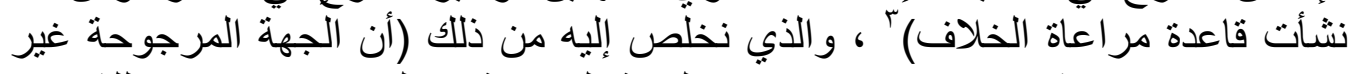

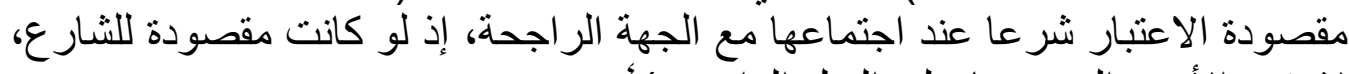

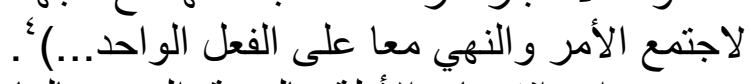

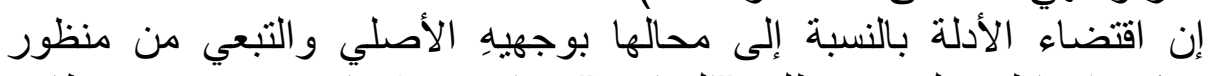

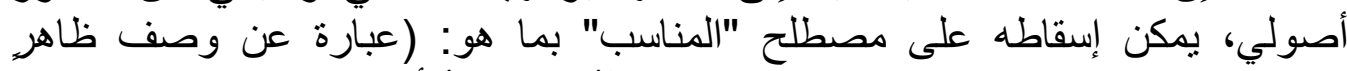

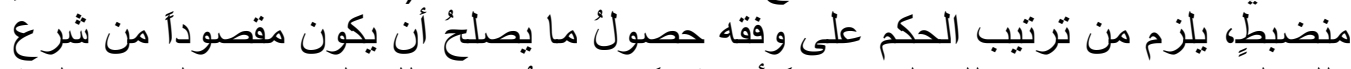

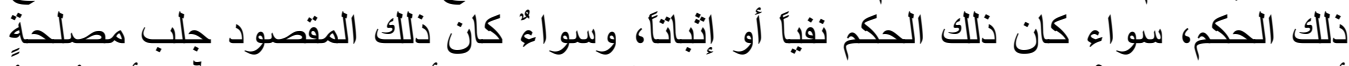

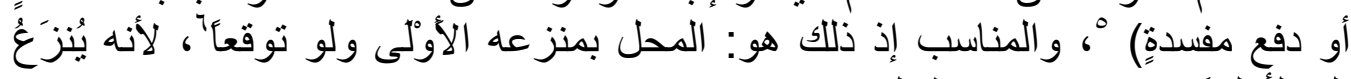

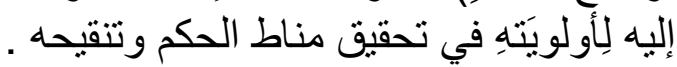

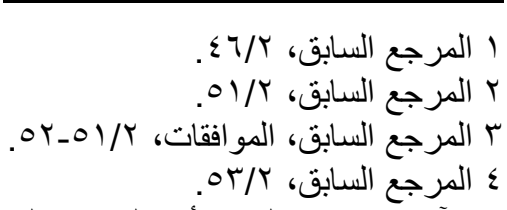

ه الآمدي، سيف الدين، أبو الحسن علي بن ابي علي بن محمد، الإحكام في أصول الأحكام، تحقيق وتعليق

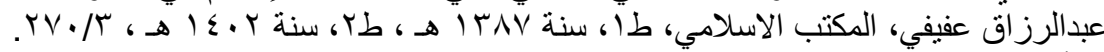

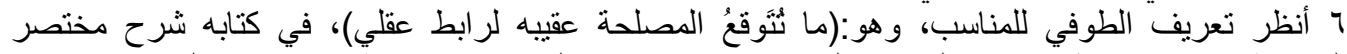

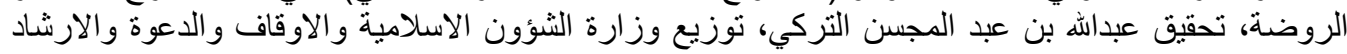

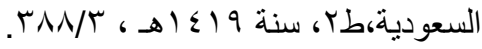




\section{الإبمث الثاله}

\section{أسس فقه الأولاريات \\ الأسساس الأول \\ مقاصد الشريعة الأسل}

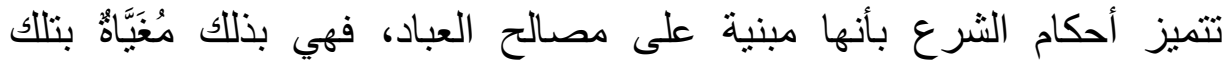

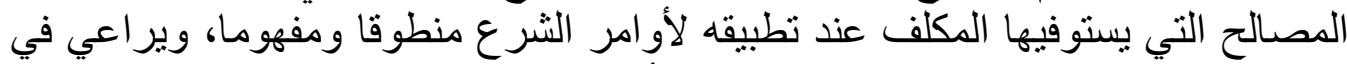

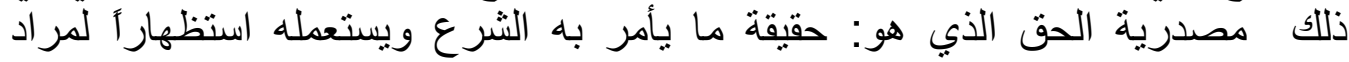

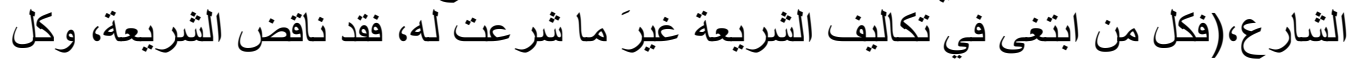

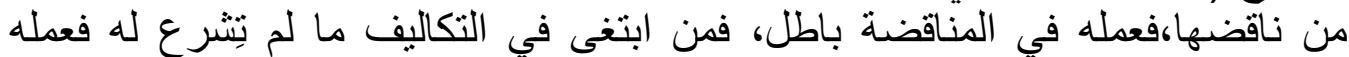

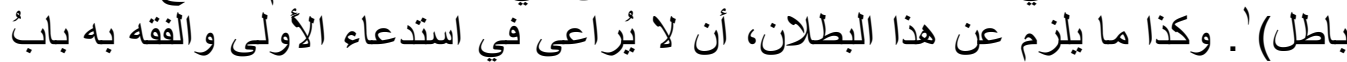

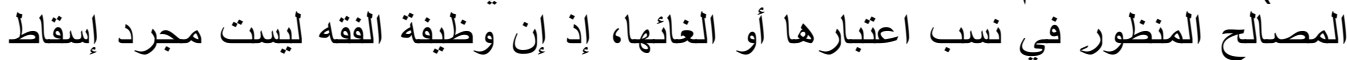

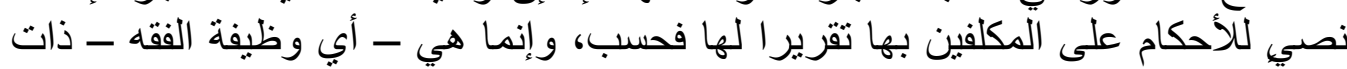

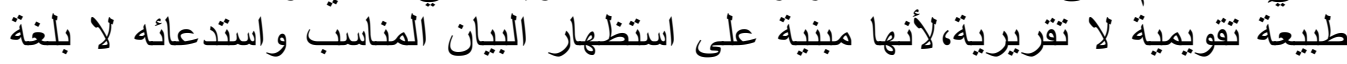

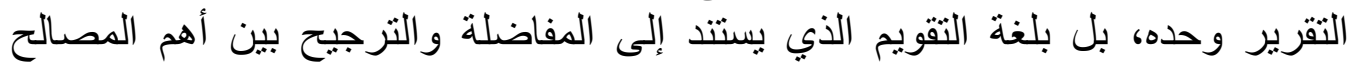

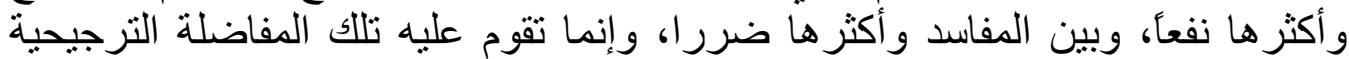

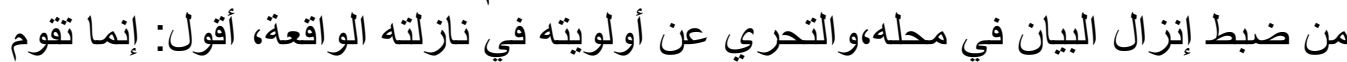

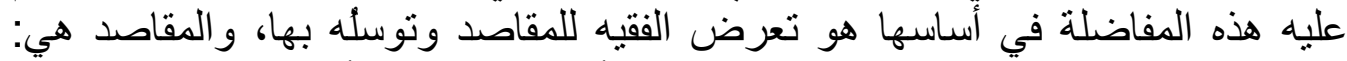

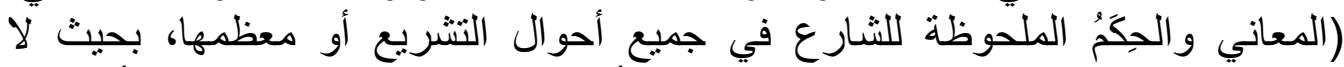

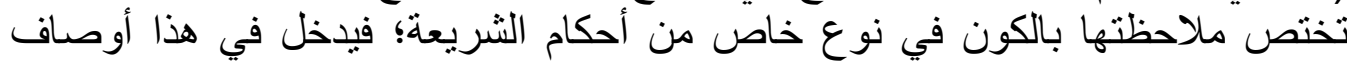

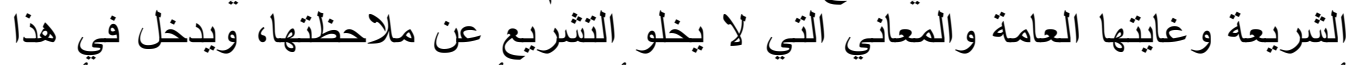

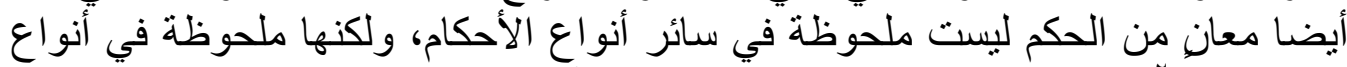

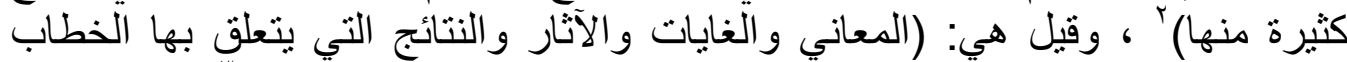

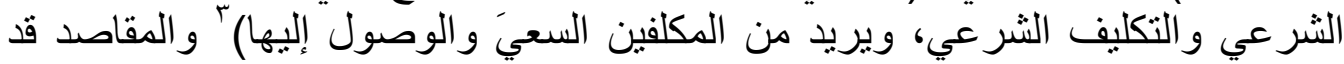

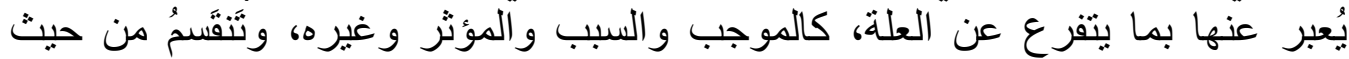

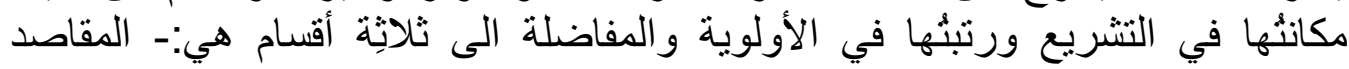

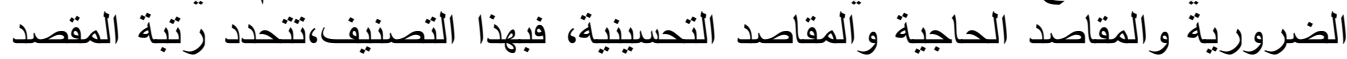

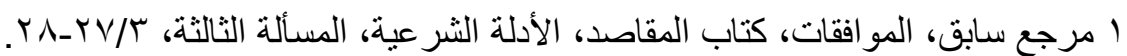

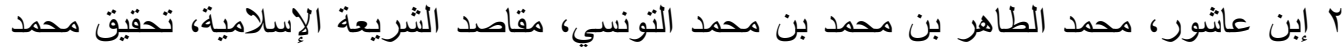

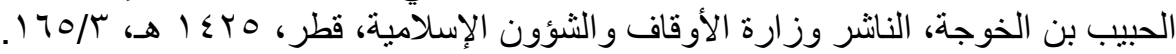

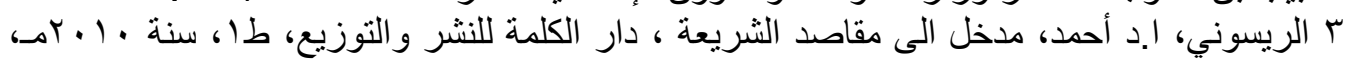


في سلم الأولويات التي يدور الفقه حولها، وهذا التحديد الرُّبي مما لا ينبغي أن يفوت الفقيةَ في تقديرهوروتوقيه في محل النازلة.

\section{الأسساس الثاني}

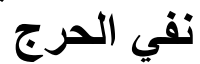

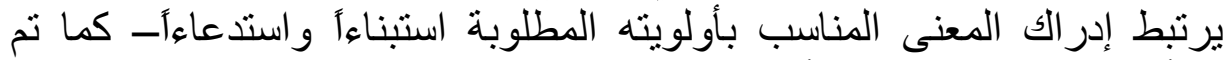
تقريره - بأساس نفي الحرج، بما أنه كلية مقاصدية، ذات التهات استحقاق تشريعي في محله،

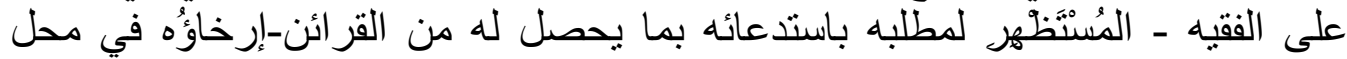

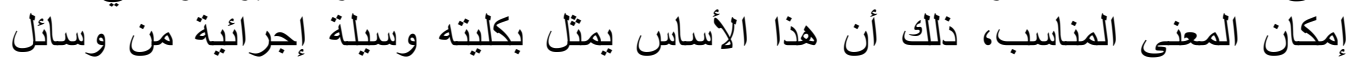

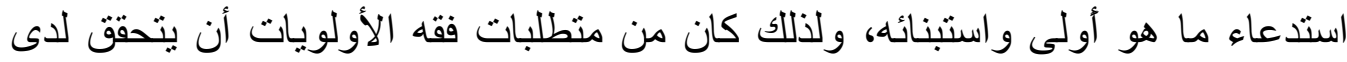

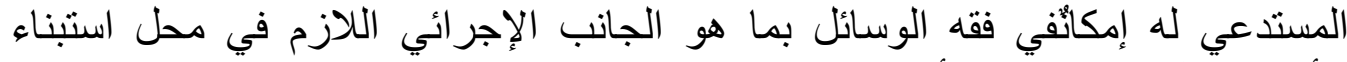

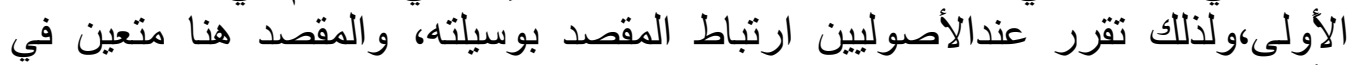

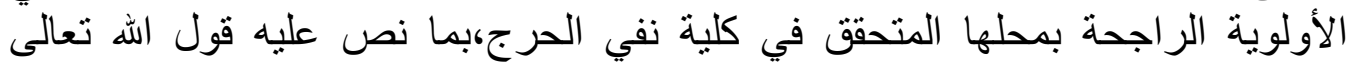

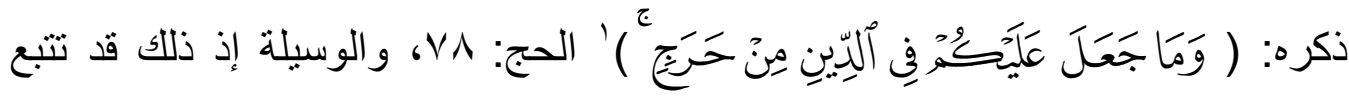

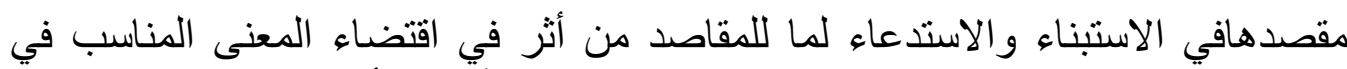

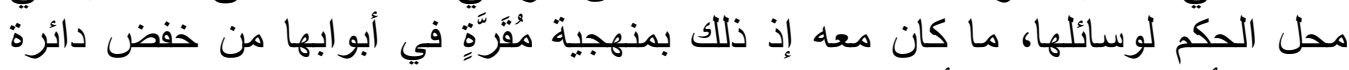
الخلاف أو الترجيح بين الأدلة.

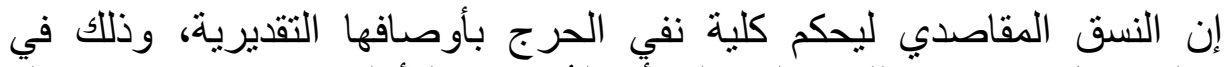

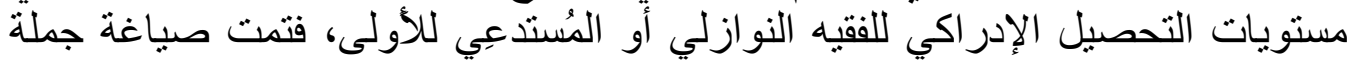

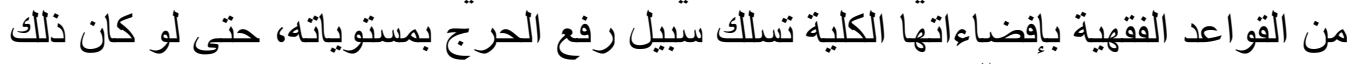

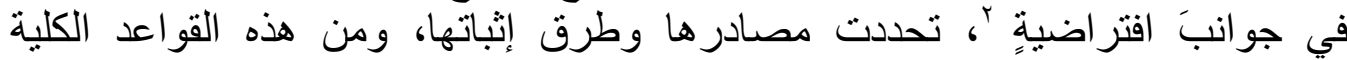

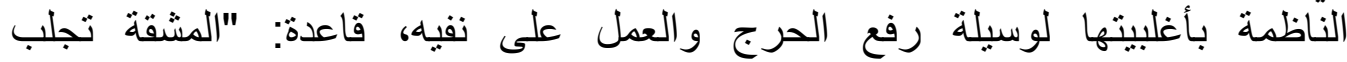

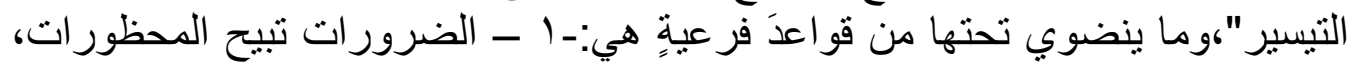

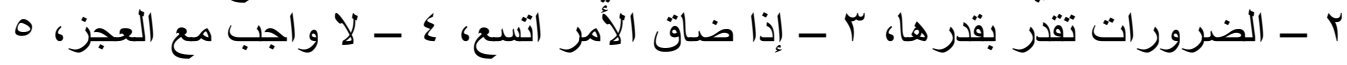

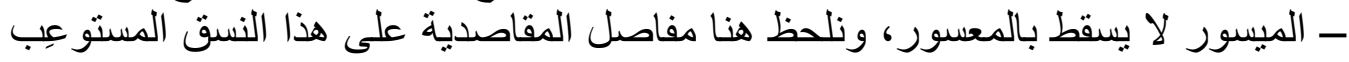

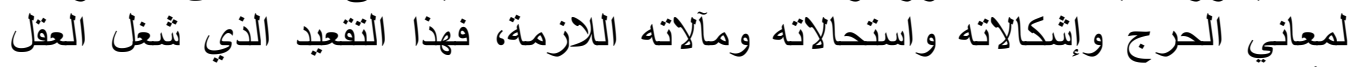

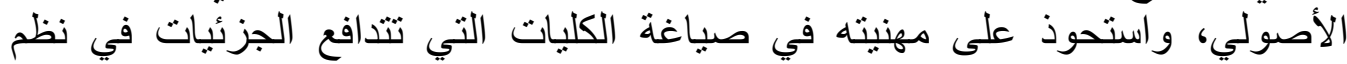

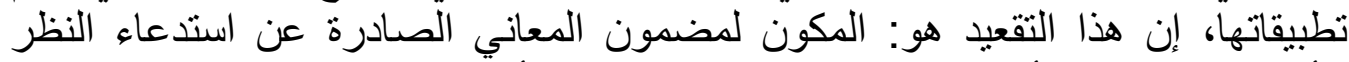

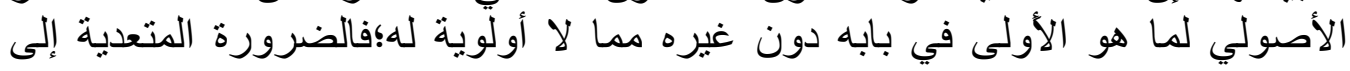

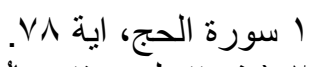

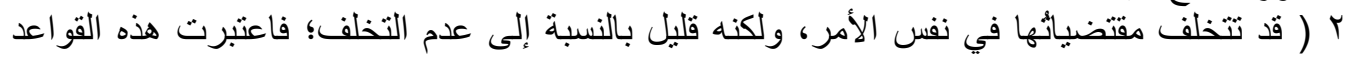

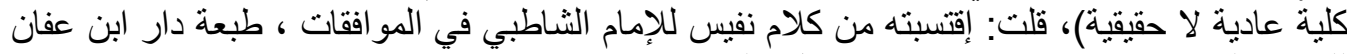

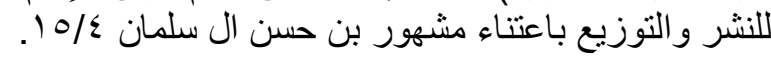


جزئية الإباحة ـ وذلك في الحقيقة وفي نفس الأمر ـ لا تخالف دليلا إلا لتوافق دليلا

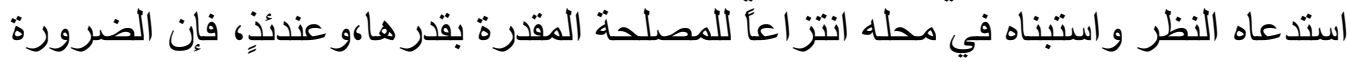

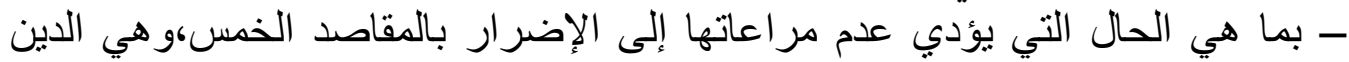

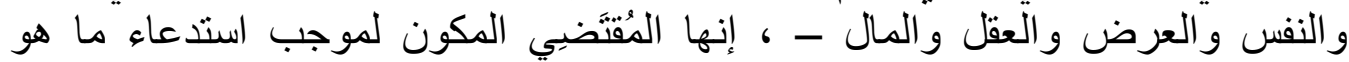

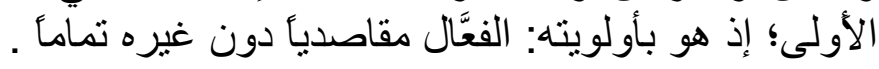

\section{الأسساس الثالث}

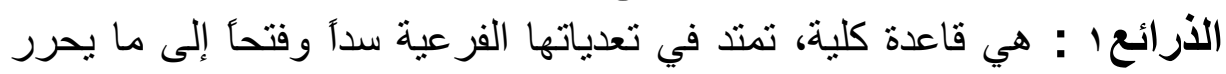

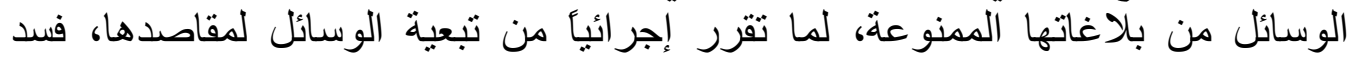

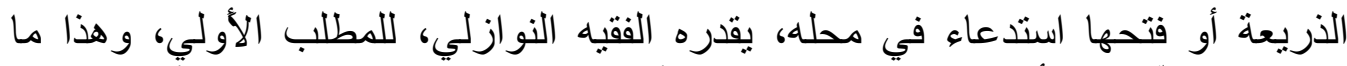

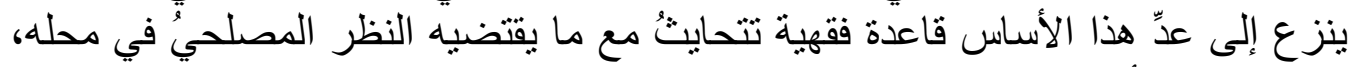

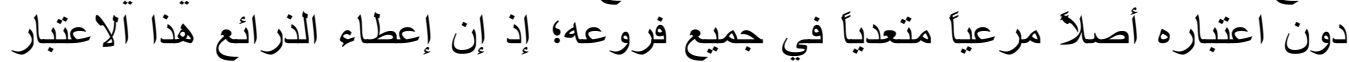

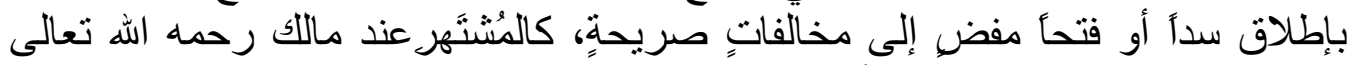

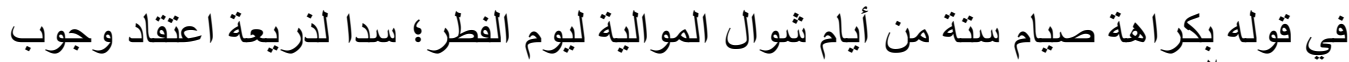

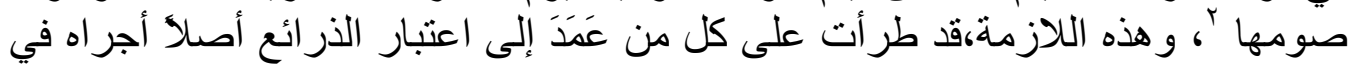

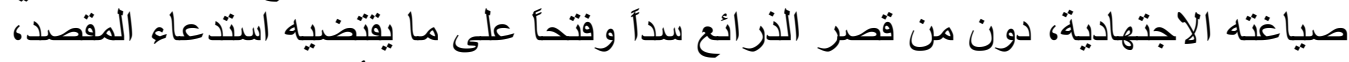

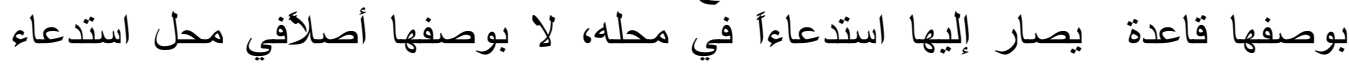
المقصد وفي غيره.

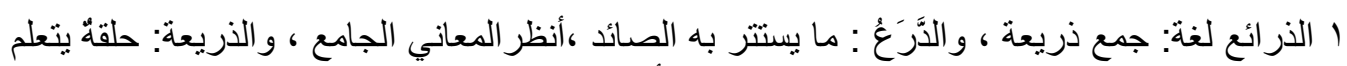

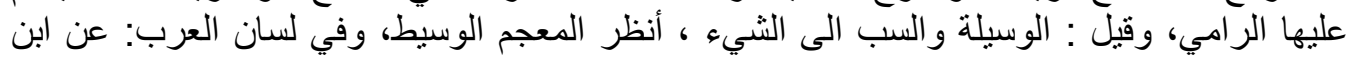

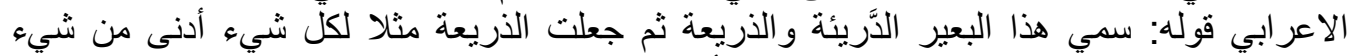

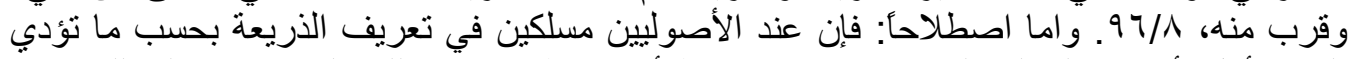

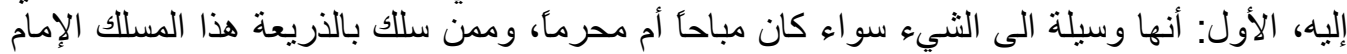

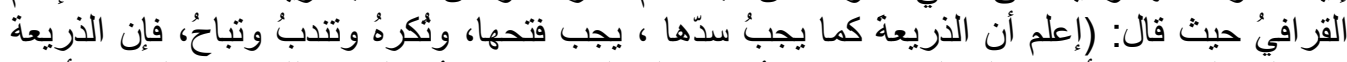

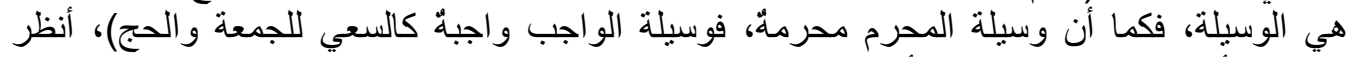

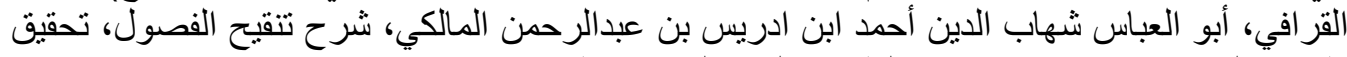

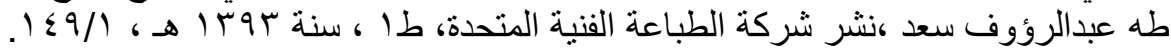

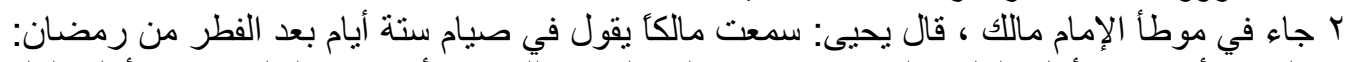

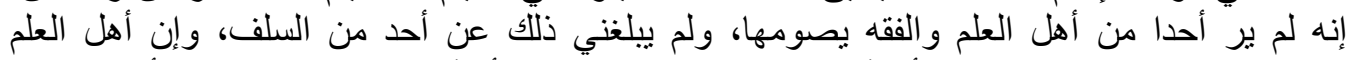

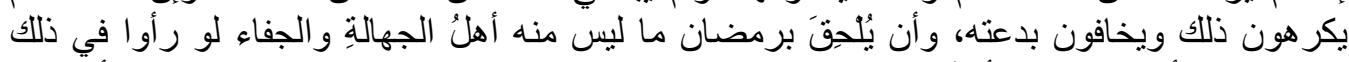

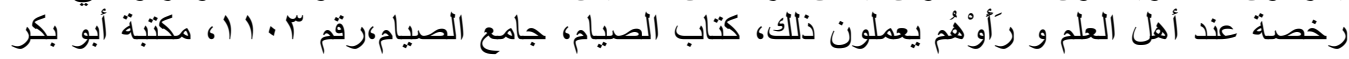


يأتي أساس الذرائع على أنه قاعدة مبنية على أصل اعتبار مآلات الأفعال، بما هي

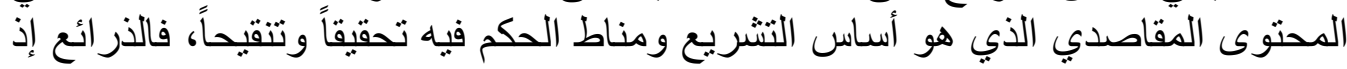

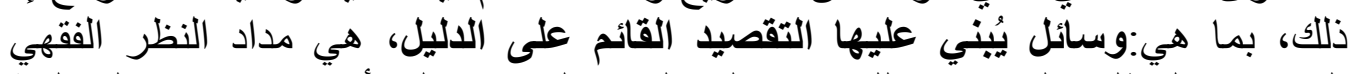

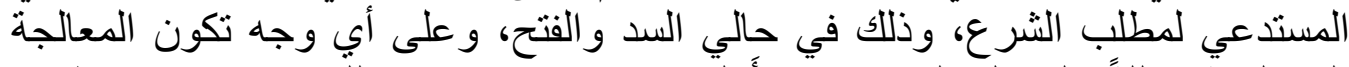

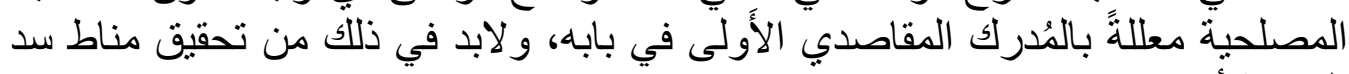
الذريعة أو فتحها وتنقيحه. معلة بالثرك.

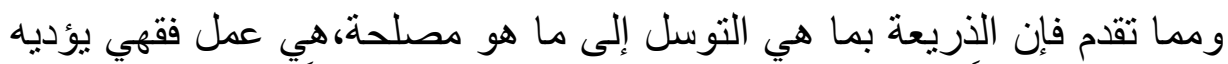

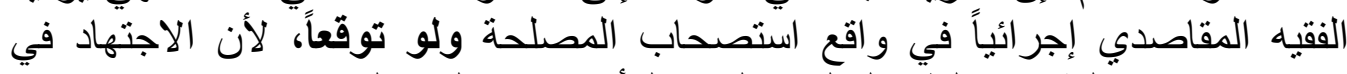

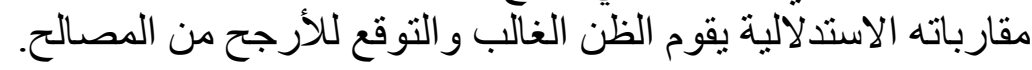

أن الذرائع أيا كان مجالها في مقاربات المجتهدين المقاصدية، يدور ورائها

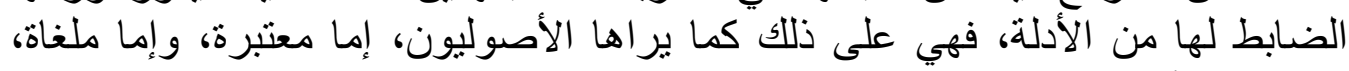

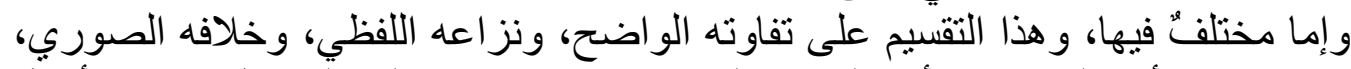

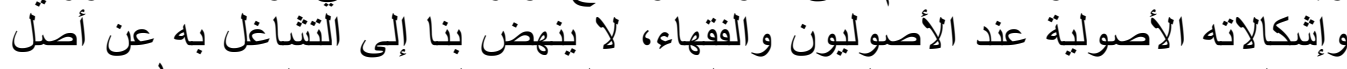

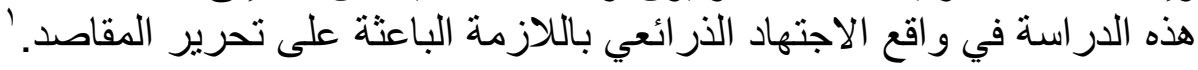

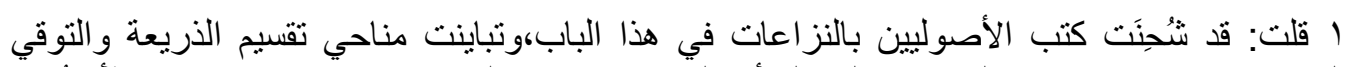

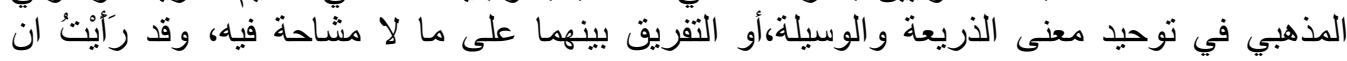
تتحصر درأستي على إطار ها في نظرية المقاصد في الاجتهاد الذرائعي الباعث على لأنى تحرير فقه ما هو

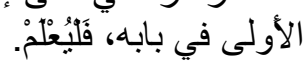




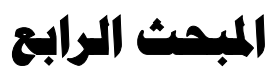

\section{أثر الاجتهاد الذرائعي في تهقيق أصول فقه الأولويات وتطبيقاته}

\section{الإقاصدية}

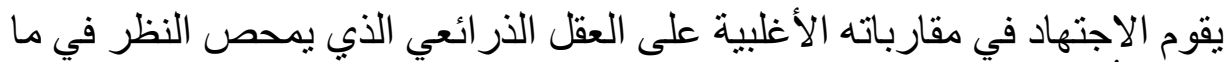

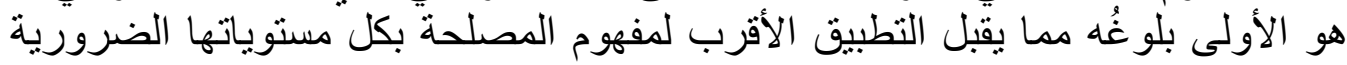

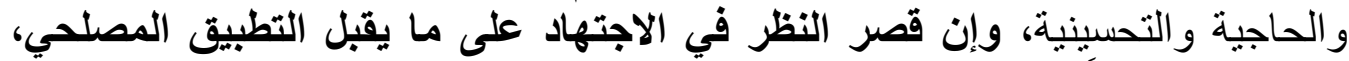

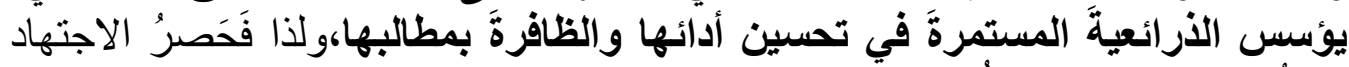

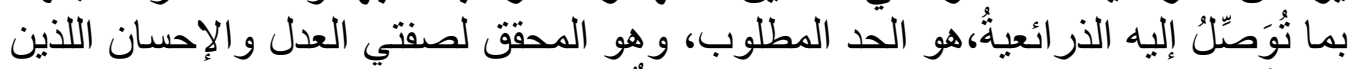

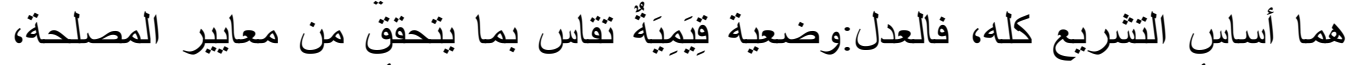

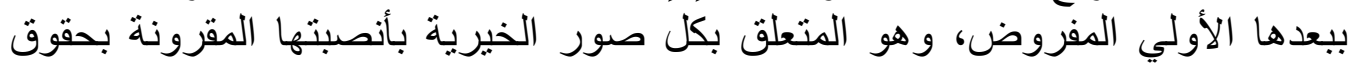

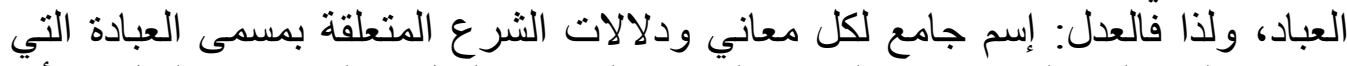

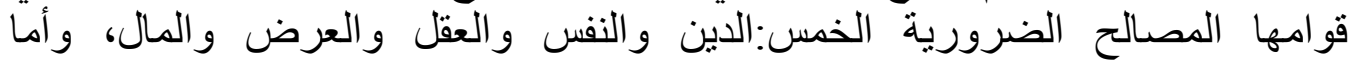

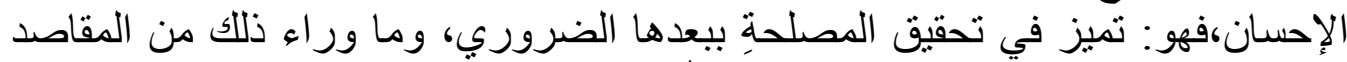

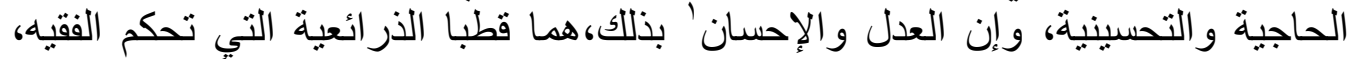

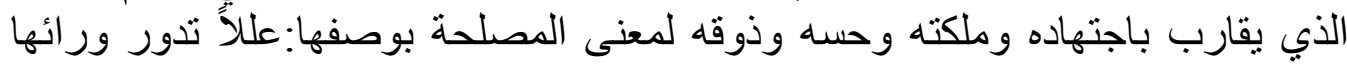

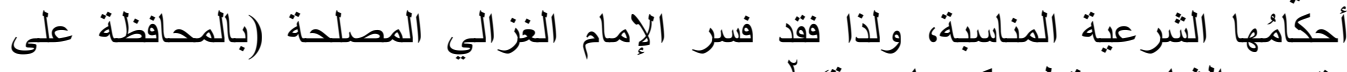

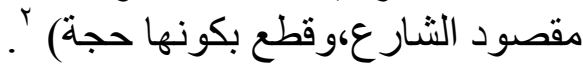

و إن مما ينبغي تحقيقه في هذا السياق،ما يكون من تداخل مصطلحات هونات هذا الباب ووحدتها

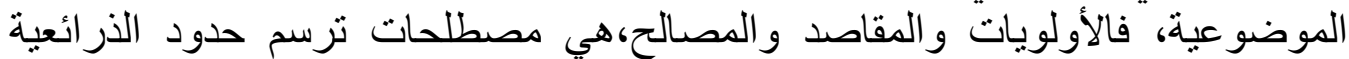

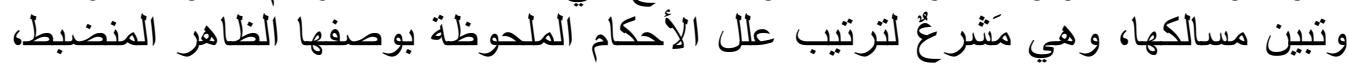

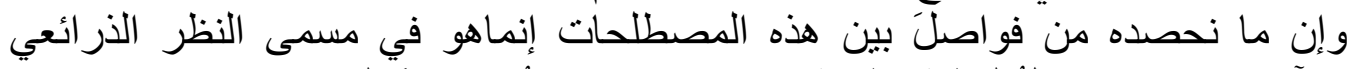

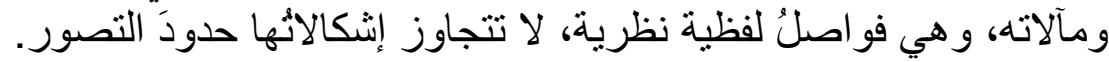

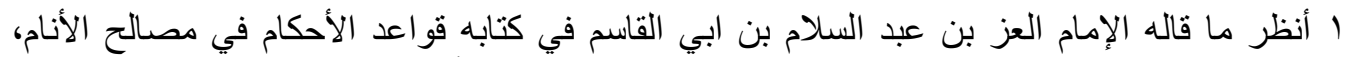

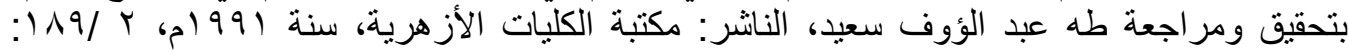

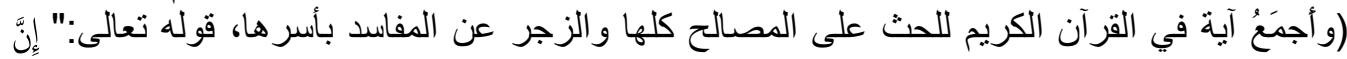

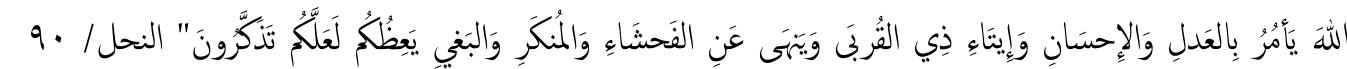

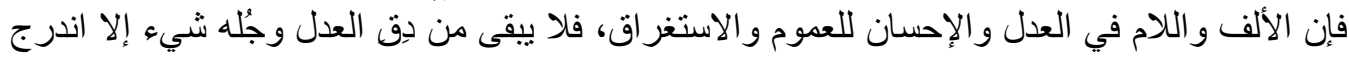

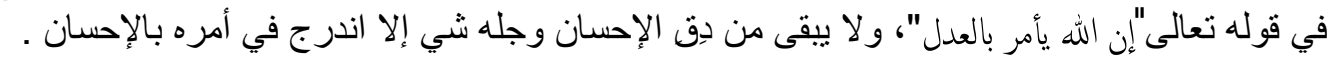

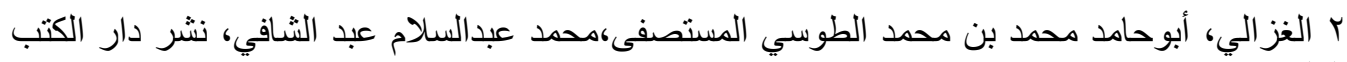

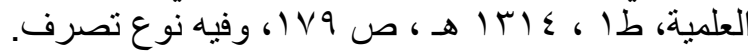




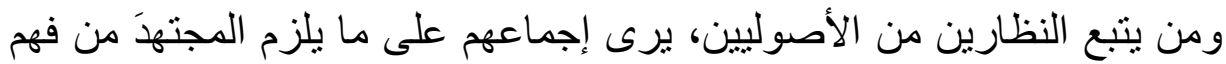

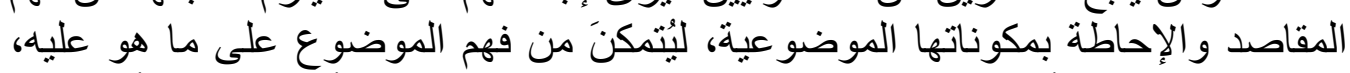

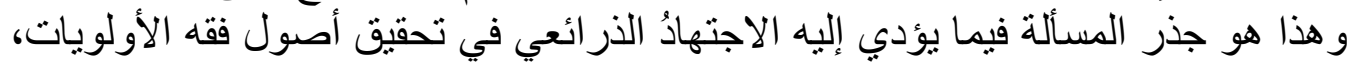

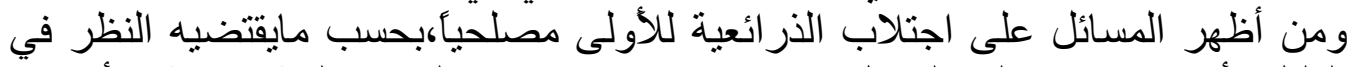

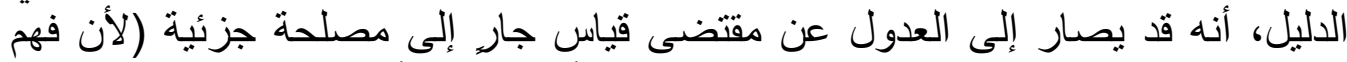

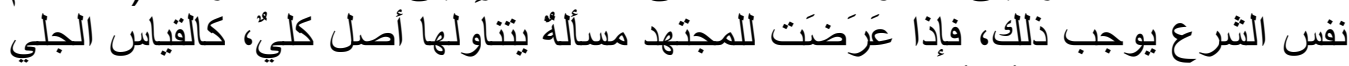

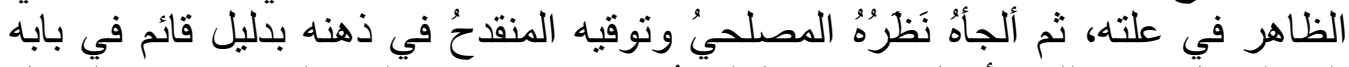

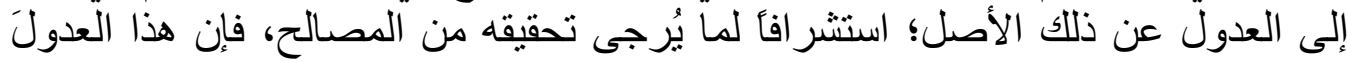

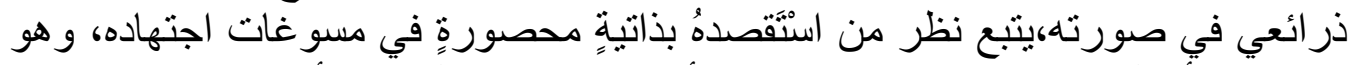

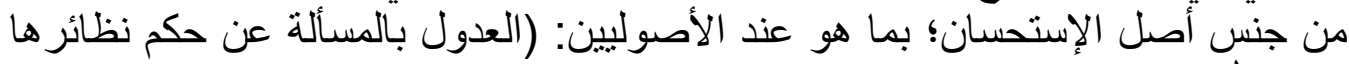

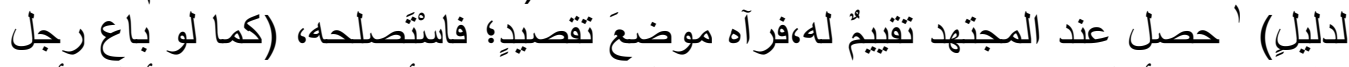

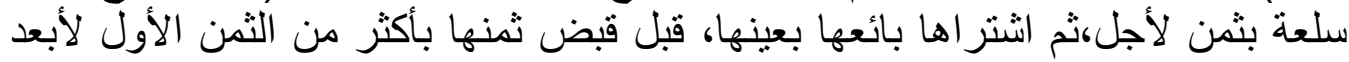

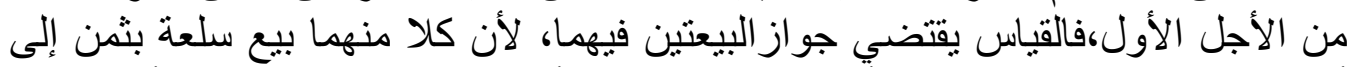

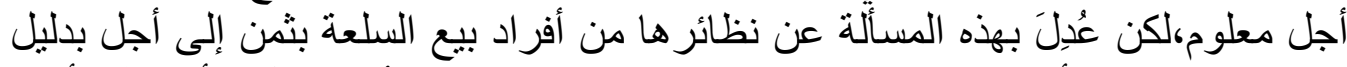

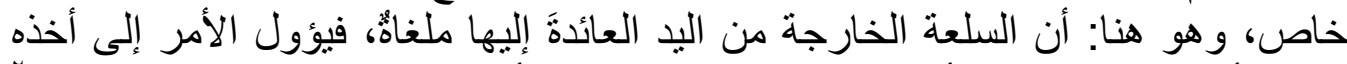

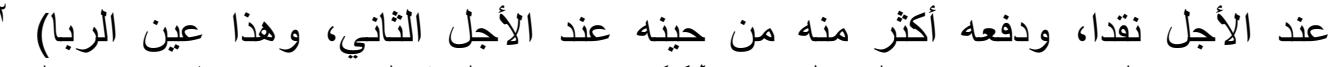

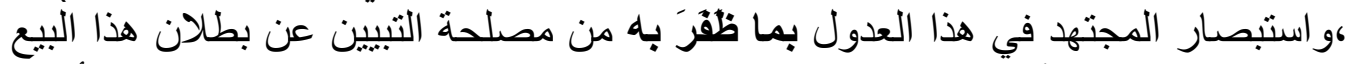

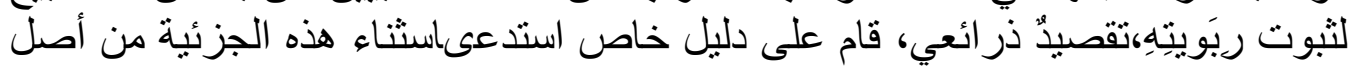

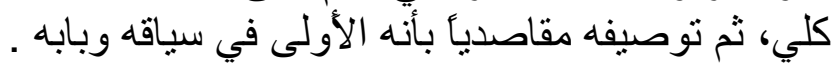

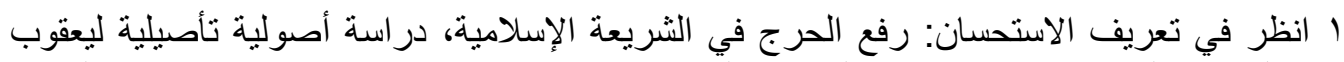

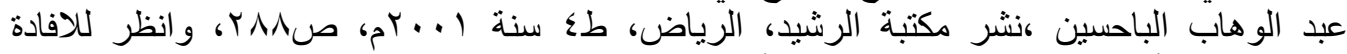

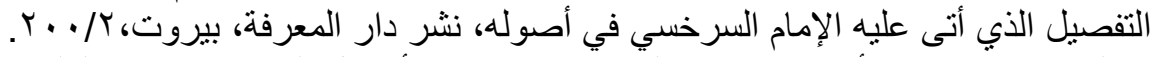

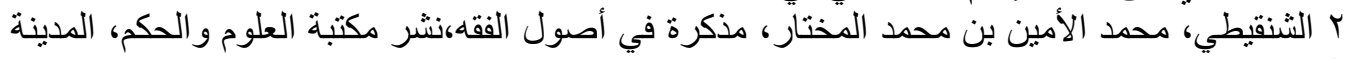

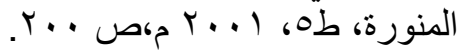




\section{المبمث الخامس}

\section{نموذج هن تطبيقات فقه الأولويات واستدلالات الأصوليين فيه}

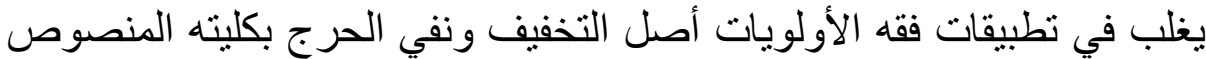

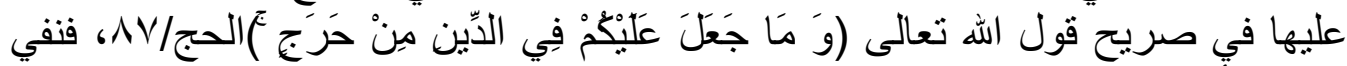

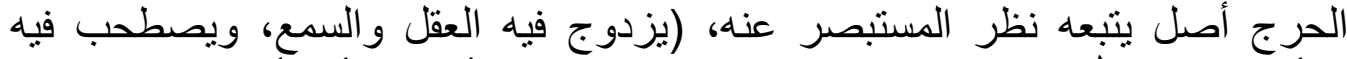

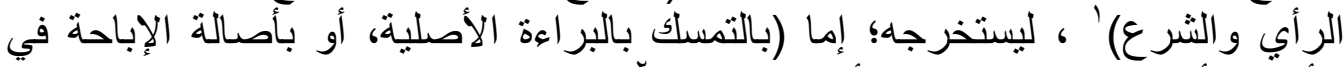

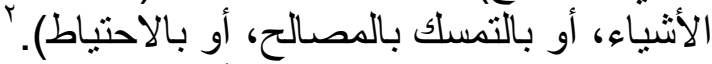

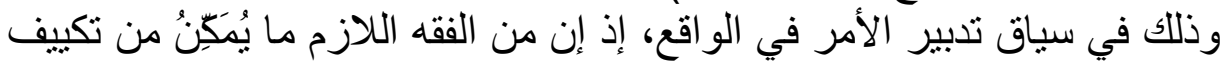

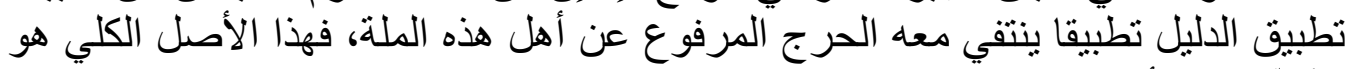

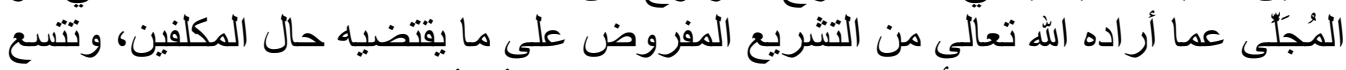

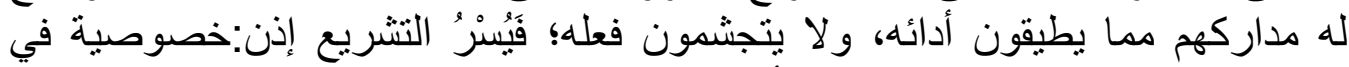

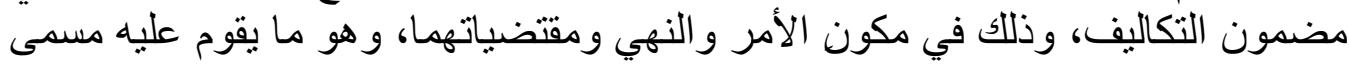

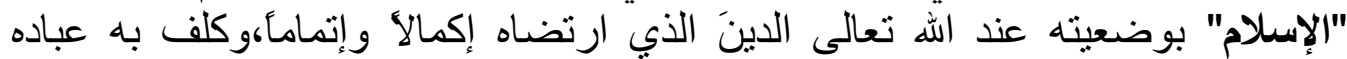

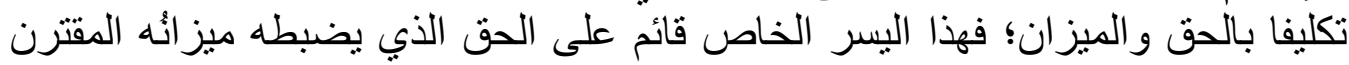
بحدود الطاقة الإدر اكية والفعلية عند المكلفين.

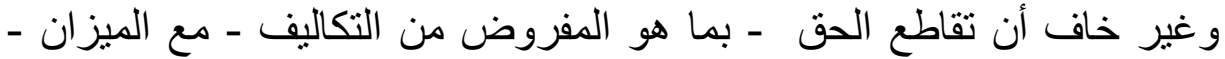

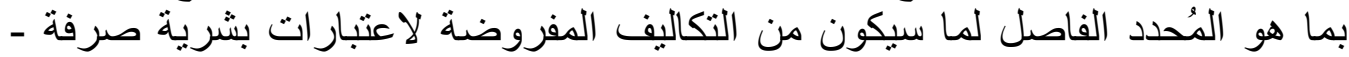

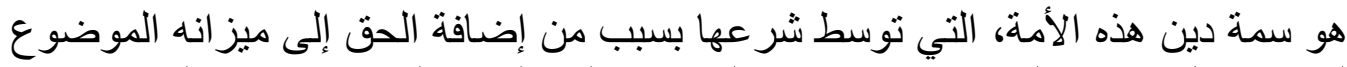

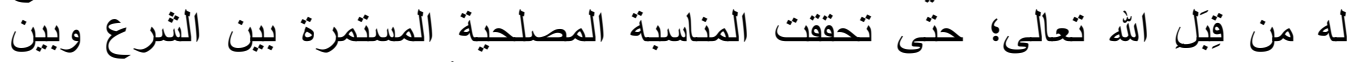

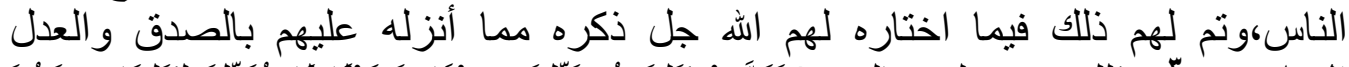

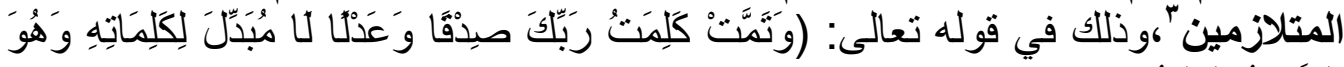

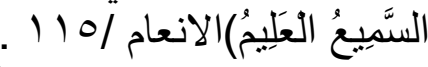

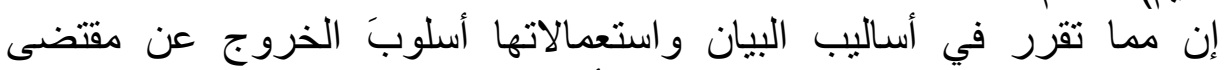

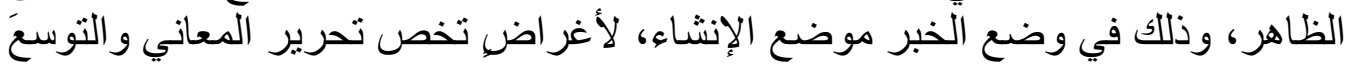

ا مرجع سابق، المستصفى للغزالي، تحقيق محمد عبد السلام عبد الثافي، المقدمة ص ء ، بنوع

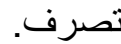

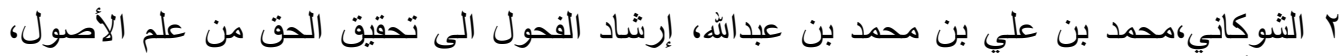

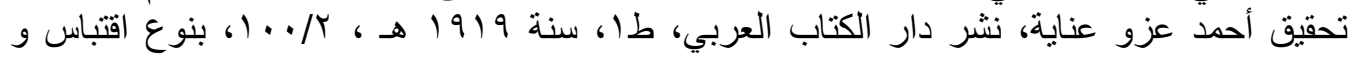

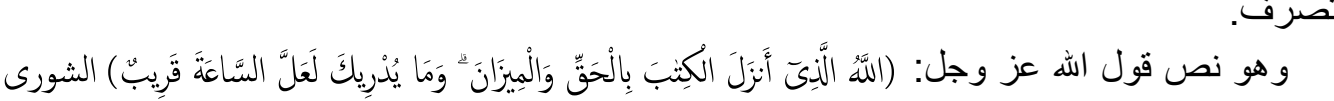




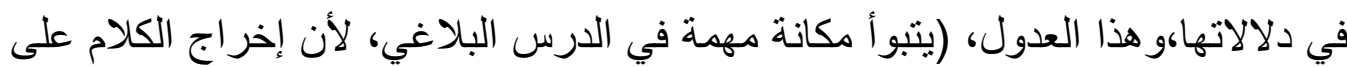

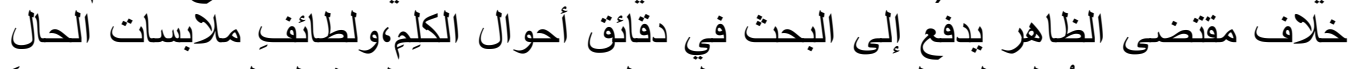

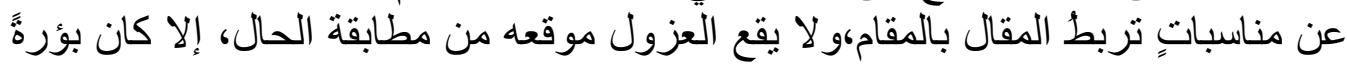

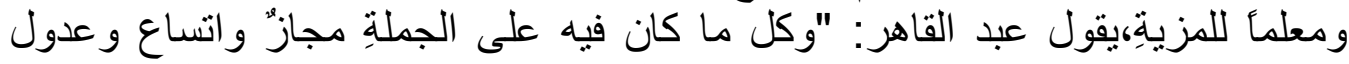

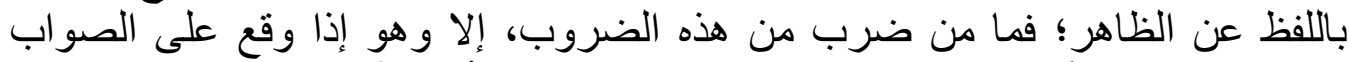

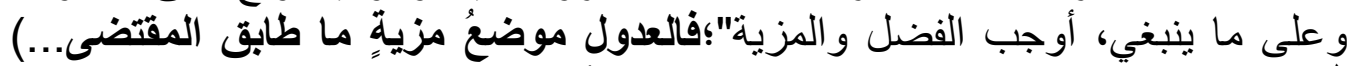

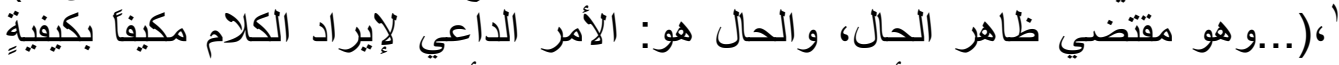

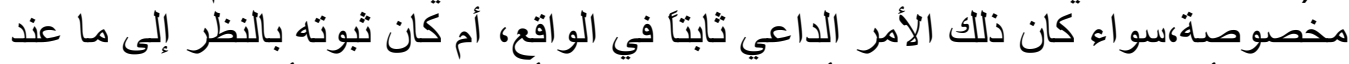

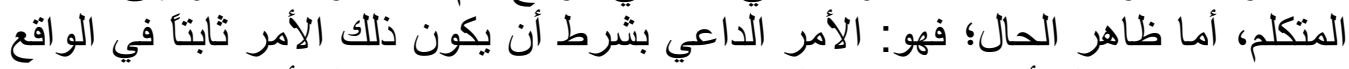

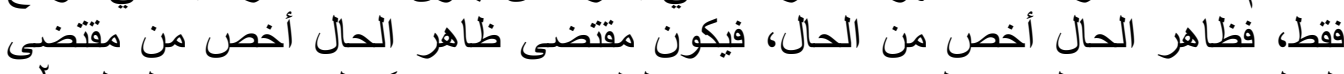

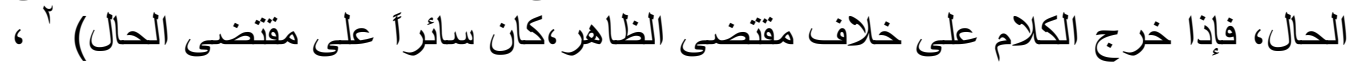

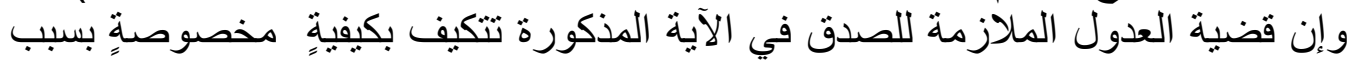

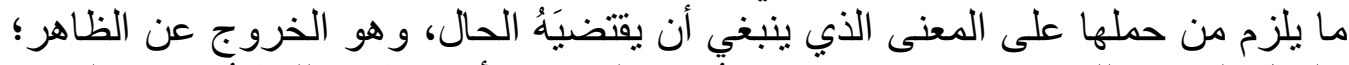

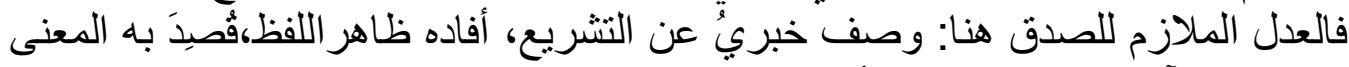

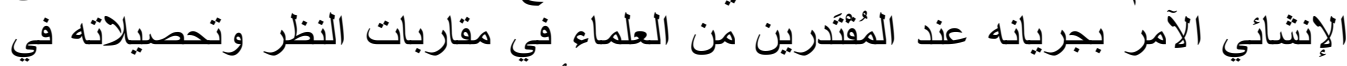

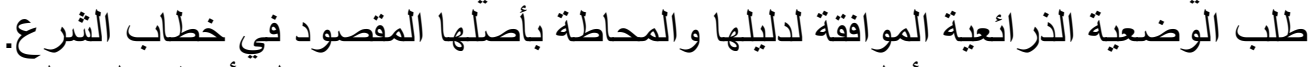

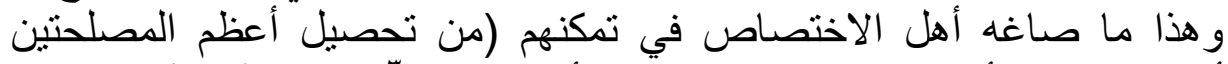

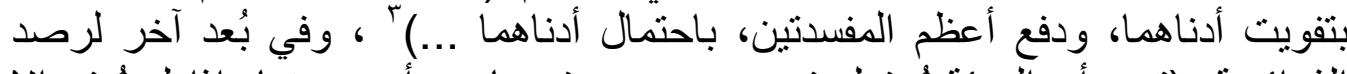

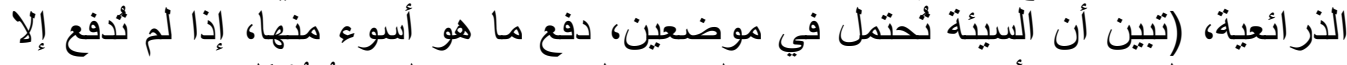

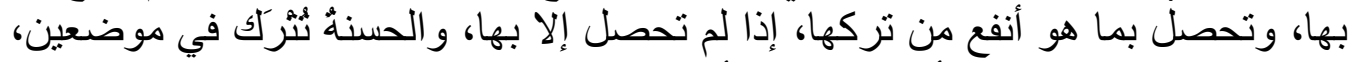

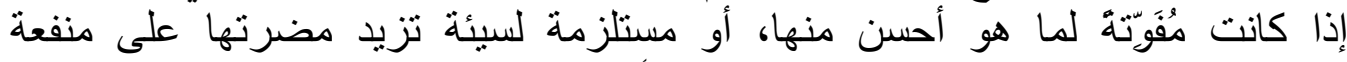

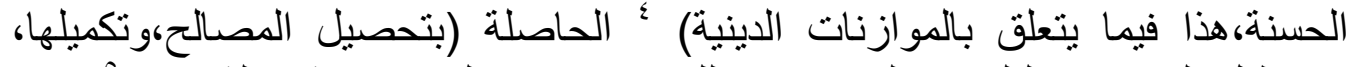

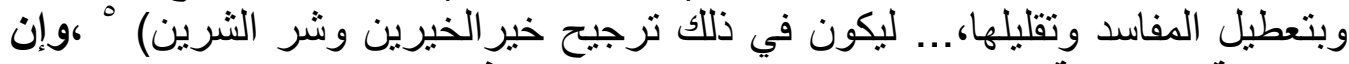

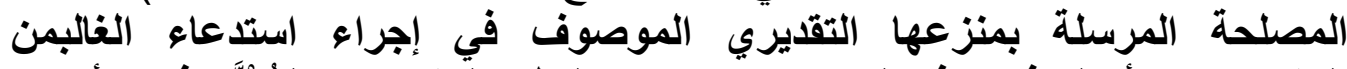

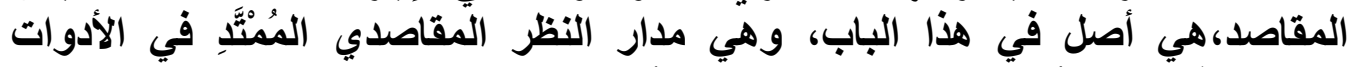

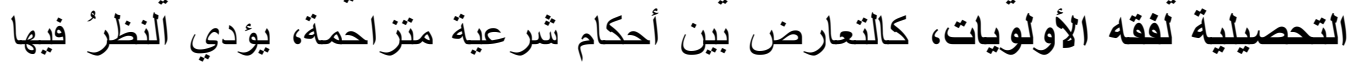

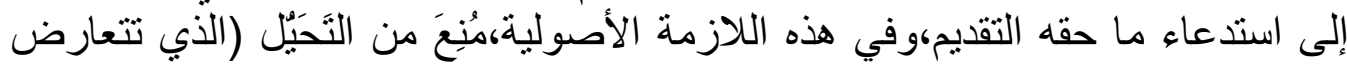

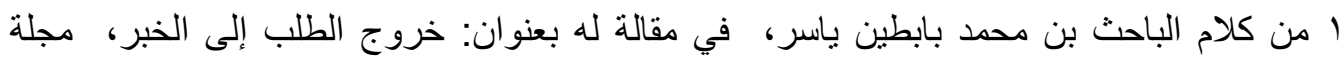

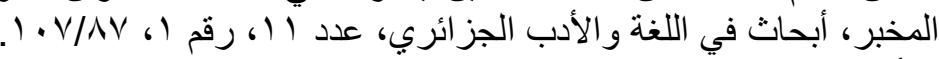

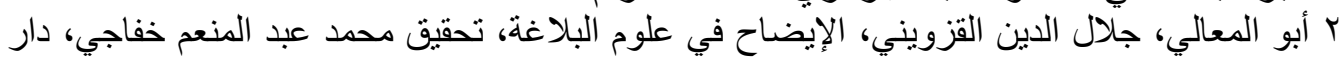

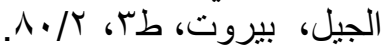

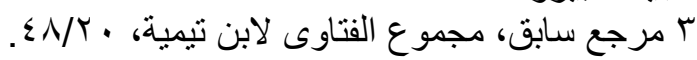

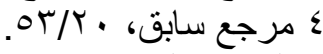

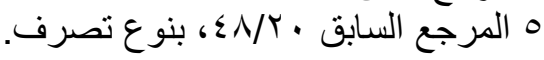


مجلة كلية الثريعة والقانون بتفهنا الأثراف ـ دقهلية

العدد الثالث والعشرون لسنة اب ـ r م الإصدار الثاني " الجزء الأول "

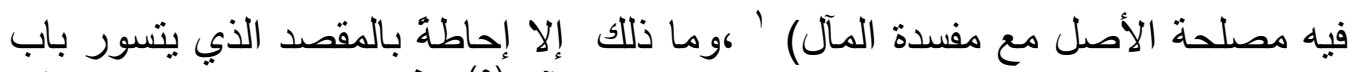

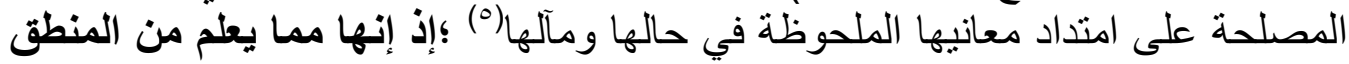

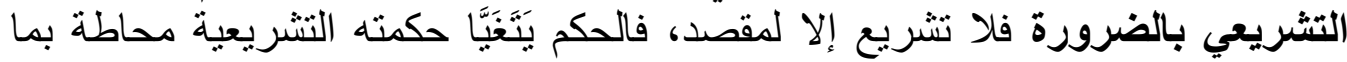
ينهض بحمايتها.

والحمدلله العظيم في هداه، الكريم في رضاه، وصلاة وسلاما على نبيه المختار

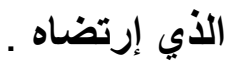

ا انظر بحث ( الفرق بين الذرائع و الحيل)، د.مصلح بن عبد الحي النجار ، وهو من منشورات الملتقى الفقهي الذي يشرف عليه د. عبدالعزيز الفوزان. دان. 


\section{المصادر والمراجع:}

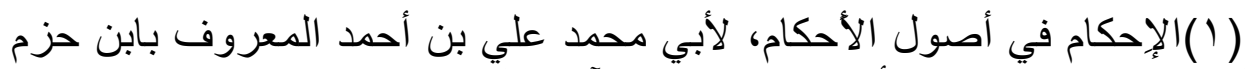
الظاهري، تحقيق محمد أحمد شاكر ، دار الآلآفاق الجديدة، بيروت.

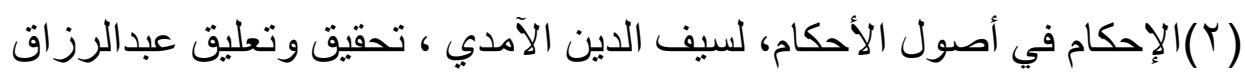

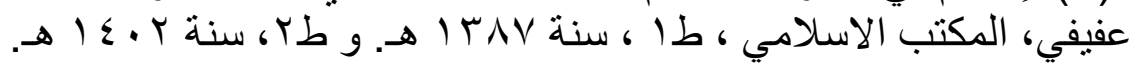

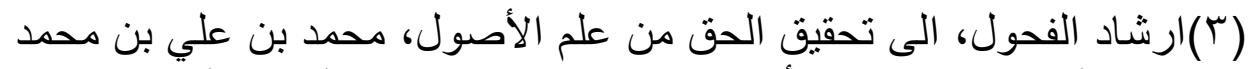

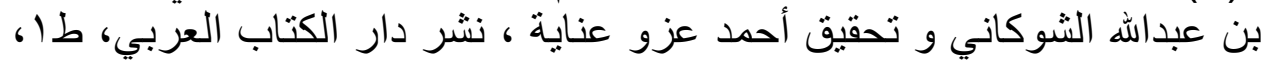
بـ 19

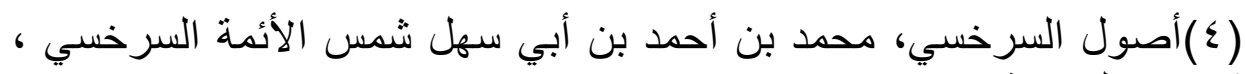

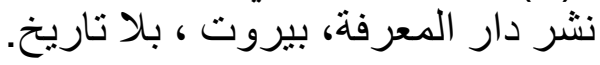

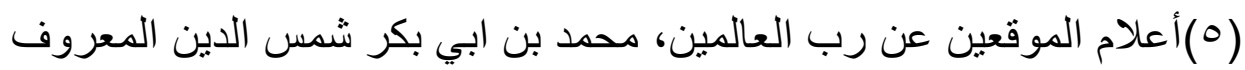

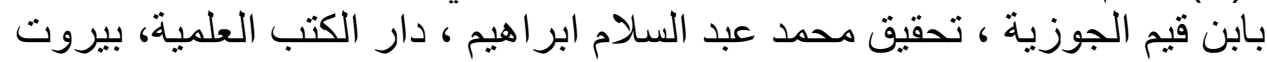

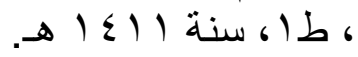

(ب)الإيضـاح في علوم البلاغةو جلال الدينه الدين القزويني، أبو المعالي، تحقيق محمد

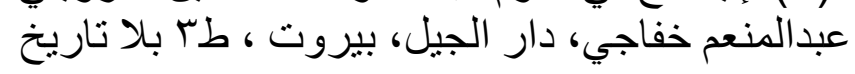

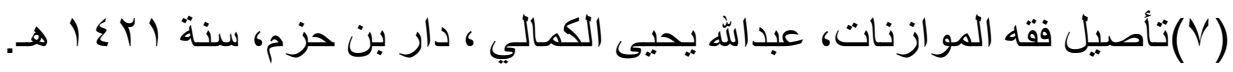

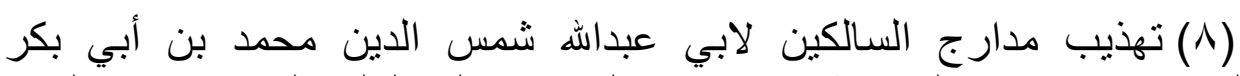

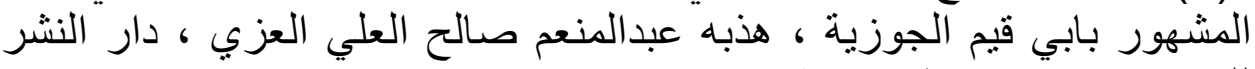

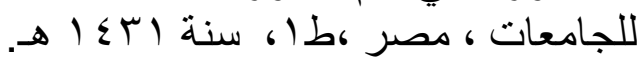

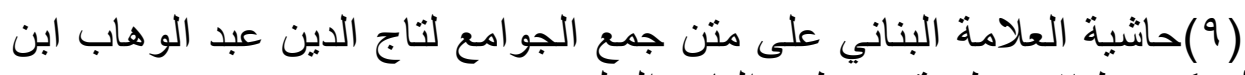

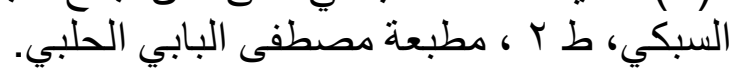

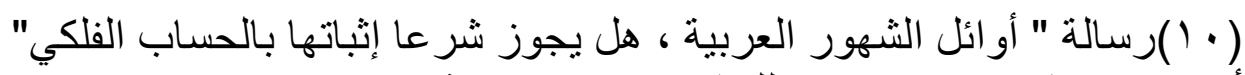

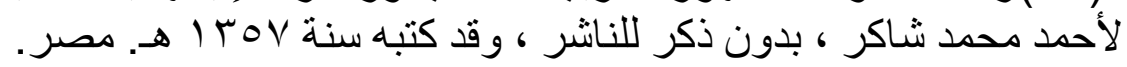

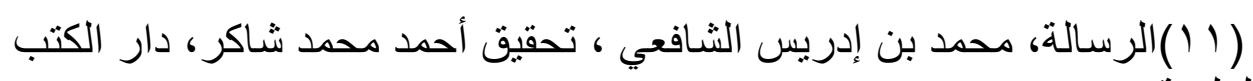
العلمية، بيروت الرسية

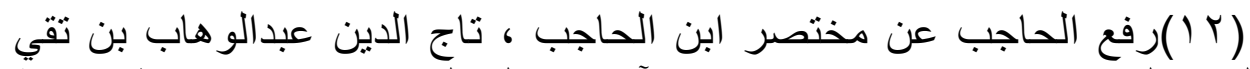

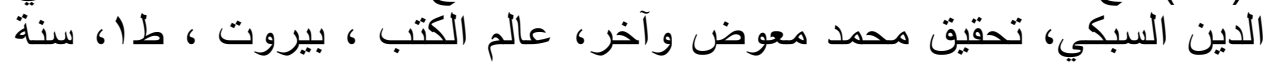

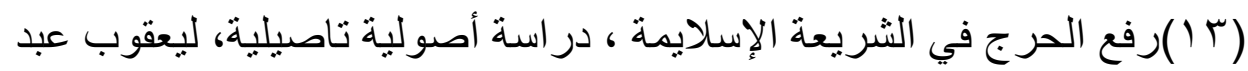

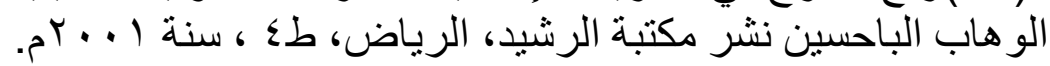




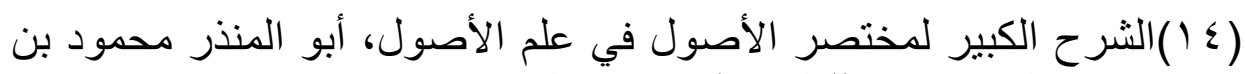

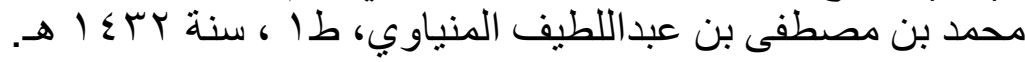

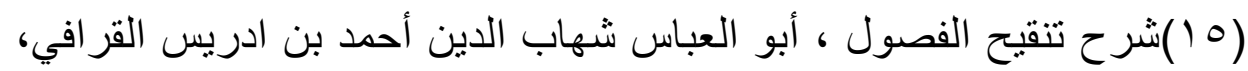

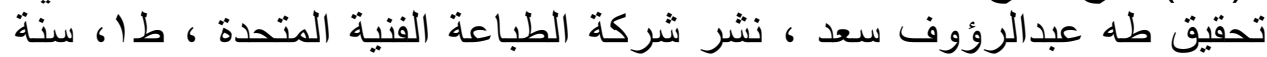
.

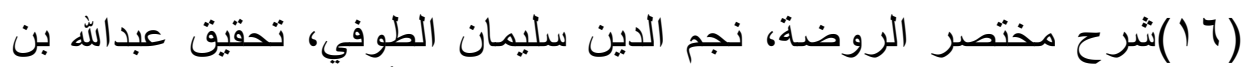

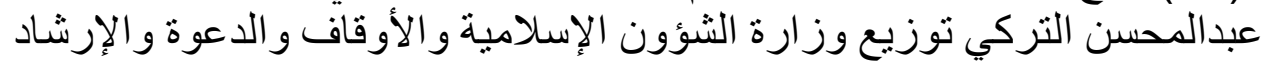

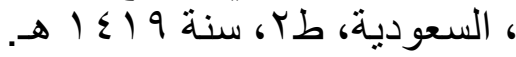

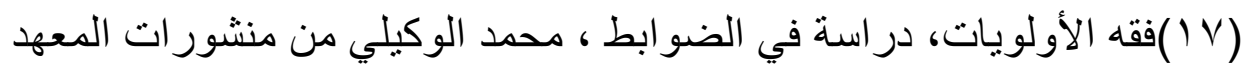

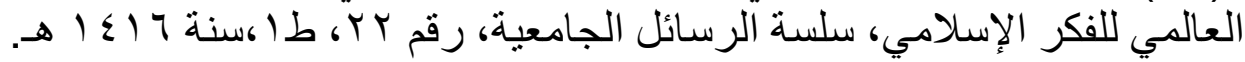

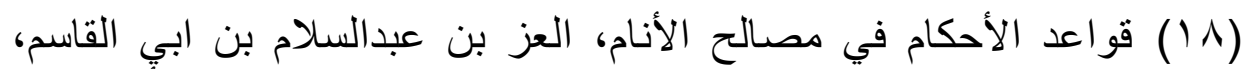

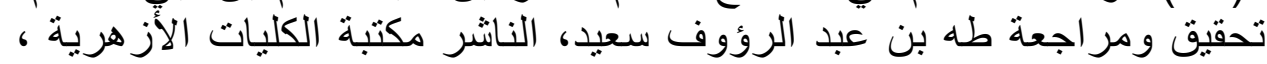

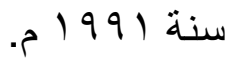

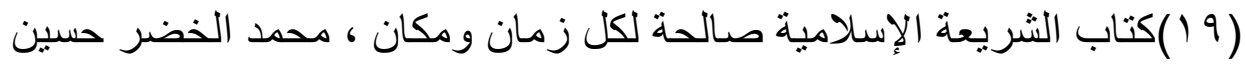

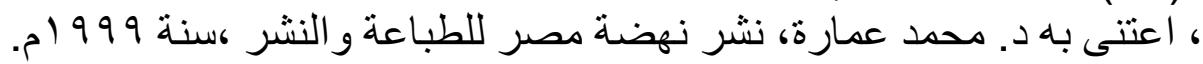

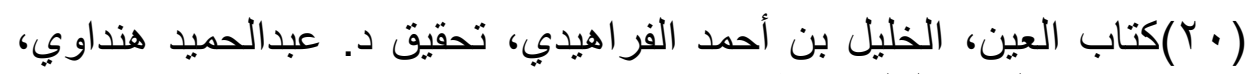

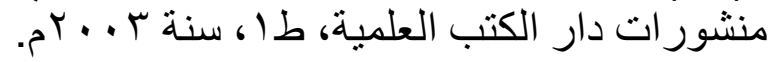

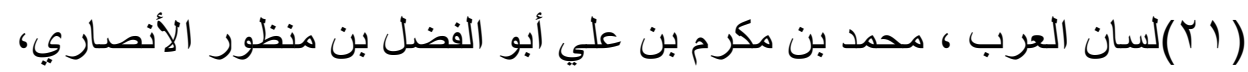

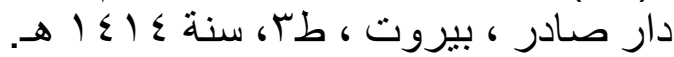

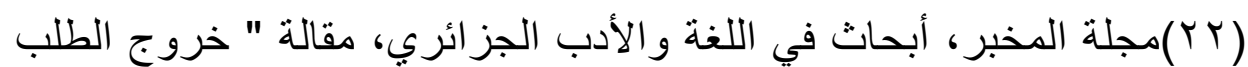

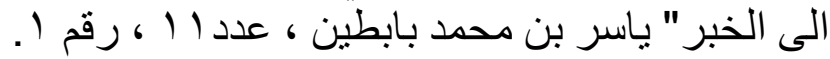

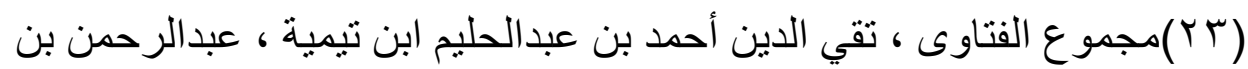

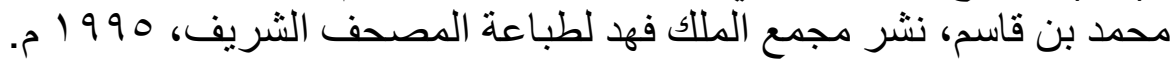

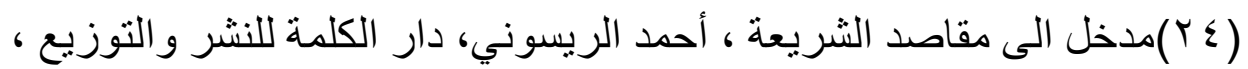

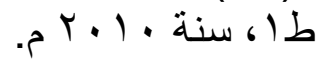

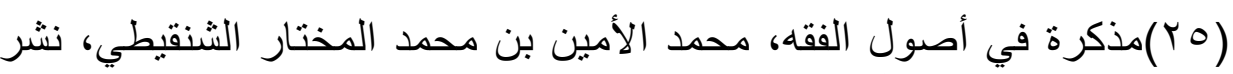

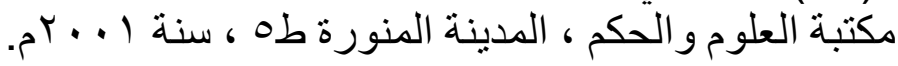

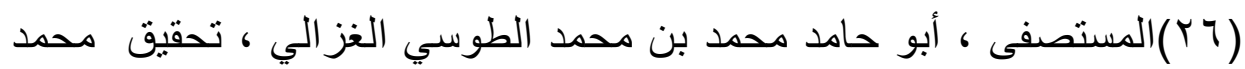

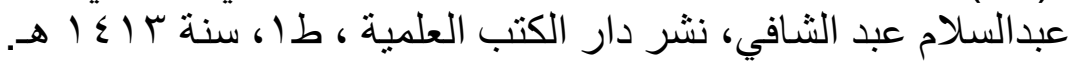




\section{"فقه الأولويات بين الوسائل والغايات،دراسة مقاصدية في الاجتهاد الذرائعي"}

(YV) المعجم العربي الأساسي ، تأليف جماعة من اللغويين العرب ، المنظمة العربية للتربية و الثقافة.

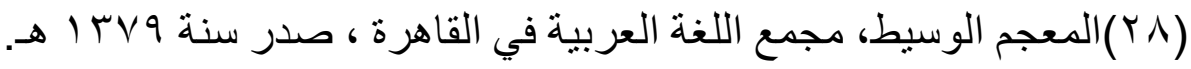

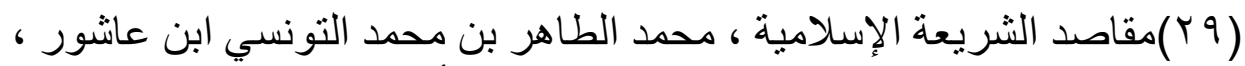

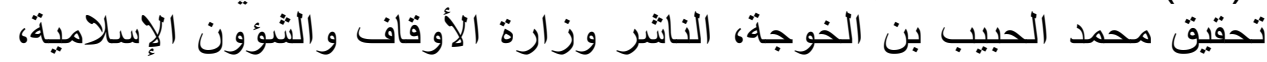

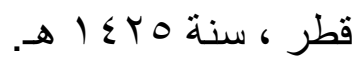

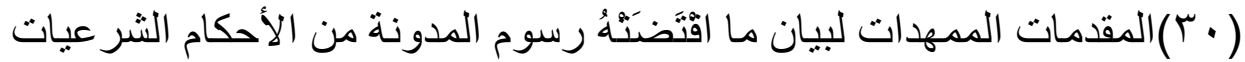

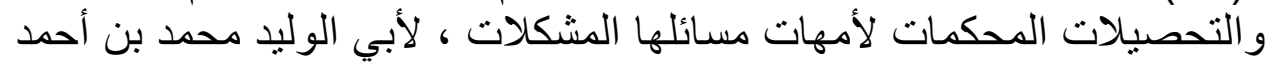

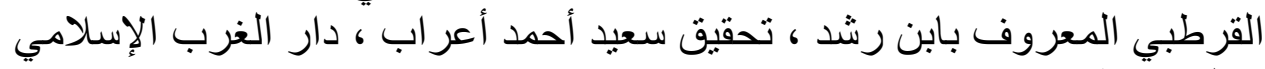

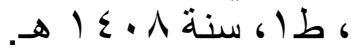

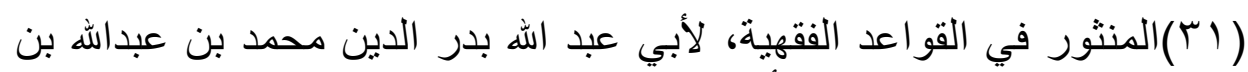

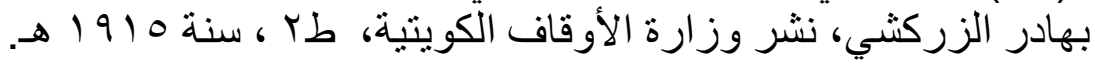

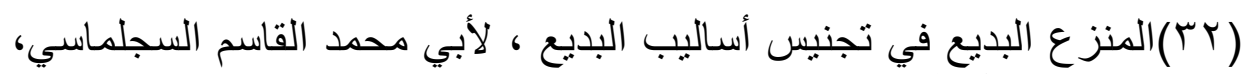

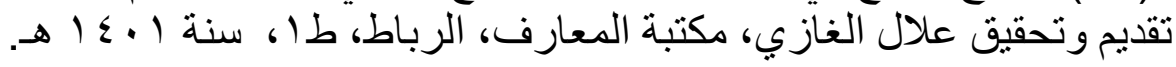

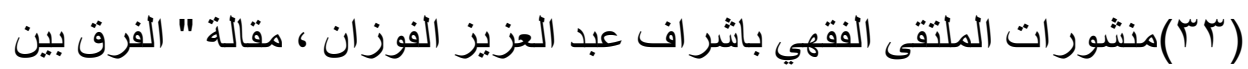

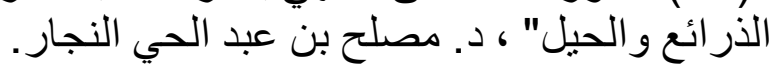

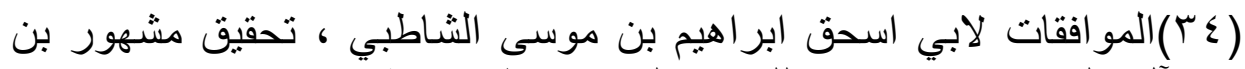

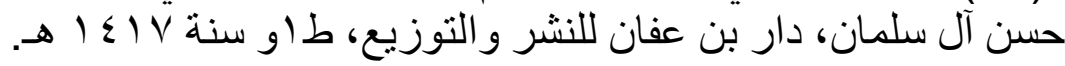

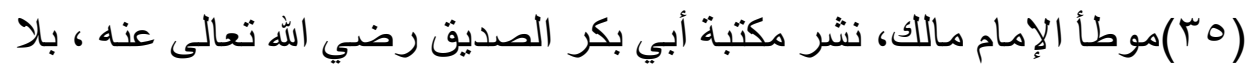
تاريخ

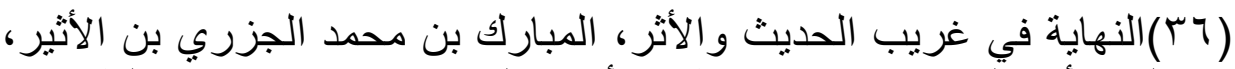

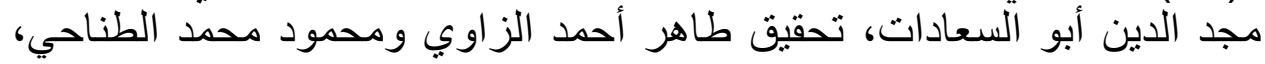

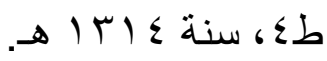

